Revista lus et Praxis, Año 17, No 2, 2011, pp. 133 - 188

ISSN 0717 - 2877

Universidad de Talca - Facultad de Ciencias Jurídicas y Sociales

"Vigencia del principio de la buena fe en el

derecho del trabajo chileno"

Pedro Irureta Uriarte

\title{
VIGENCIA DEL PRINCIPIO DE LA BUENA FE EN EL DERECHO DEL TRABAJO CHILENO***
}

\author{
VALIDITY OF THE PRINCIPLE OF GOOD FAITH IN THE CHILEAN LABOR LAW
}

Pedro IruReta Uriarte ${ }^{* * *}$

\begin{abstract}
RESUMEN
La buena fe es un principio general del Derecho que, en el ámbito laboral, encuentra especial aplicación en la figura del contrato de trabajo. La buena fe es predicable tanto para el trabajador como para el empleador, y se verifica en los estadios previos a la contratación, durante el desarrollo mismo del contrato, así como al momento de la extinción. El Código del Trabajo chileno, sin referirse expresamente a este principio, ha terminado incorporando sus exigencias en distintas figuras laborales; cuestión que no impide que el núcleo esencial del principio se despliegue en toda su magnitud al momento de configurar los derechos y obligaciones de cada parte.
\end{abstract}

ABSTRACT

Good faith is a general principle of law which, in the workplace, finds special application in the employment contract. This principle acts both from the worker and the employer and has to be present in stages prior to recruitment, during the fulfillment of the contract and the date of termination. The Chilean Labour Code, without explicitly

* Trabajo recibido el 15 de agosto y aprobado el 5 de septiembre de 2011.

** Abreviaturas: AAMN (Anales de la Academia Matritense del Notariado); ADC (Anuario de Derecho Civil); $\mathrm{ADCU}$ (Anuario de Derecho Civil Uruguayo); $\mathrm{ADH}$, Nueva Época (ADH); AJ (Actualidad Jurídica); AL (Actualidad Laboral); AS (Aranzadi Social); BAG (Tribunal Federal del Trabajo); BGB (Código Civil alemán); CC (Código Civil); CCDT (Cuadernos de la Cátedra de Derecho del Trabajo); CDP (Cuadernos de Derecho Público); COT (Código Orgánico de Tribunales); CP (Código Penal); CPC (Código de Procedimiento Civil); CPR (Constitución Política de la República); CT (Código del Trabajo); DL (Documentación Laboral); DO (Diario Oficial); GJ (Gaceta Jurídica); OIT (Organización Internacional del Trabajo); RAP (Revista de Administración Pública); RCDI (Revista Crítica de Derecho Inmobiliario); RCHD (Revista Chilena de Derecho); RDCP (Revista de Derecho y Ciencias Penales); RDPUCV (Revista de Derecho Pontificia Universidad Católica de Valparaíso); RDD (Revista de Derecho); RDDUC (Revista de Derecho Universidad de Concepción); RDJ (Revista de Derecho y Jurisprudencia y Gaceta de los Tribunales); RDP (Revista de Derecho Privado); RDS (Revista de Derecho Social); RDT (Revista de Derecho del Trabajo); RDTR (Revista de Trabajo); REDC (Revista Española de Derecho Constitucional); REDT (Revista Española de Derecho del Trabajo); RFDM (Revista de la Facultad de Derecho de México); RFM (Revista Fallos del Mes); RGLJ (Revista General de Legislación y Jurisprudencia); RIDP (Revista Iberoamericana de Derecho Procesal); RJC (Revista Jurídica de Cataluña); RLCH (Revista Laboral Chilena); RPS (Revista de Política Social); RTDPC (Revista Trimestrale di Diritto e Procedura Civiles); RTL (Revista Técnico Laboral); RTSS (Revista de Trabajo y Seguridad Social); TDD (Temas de Derecho).

*** Licenciado en Derecho por la Pontificia Universidad Católica de Chile; Doctor en Derecho por la Universidad Complutense de Madrid; Profesor titular de Derecho del Trabajo de la Universidad Alberto Hurtado. Correo electrónico: piruret@uahurtado.cl. 
referring to this principle, has incorporated its work demands in different shapes. This special technique does not interfere with a direct spillover of the legal core of that principle when the legal order configures the rights and obligations of each party.

\author{
Palabras Clave \\ Buena Fe, Contrato de Trabajo, Principios
}

KEY WORDS

Good Faith, Work Contract, Principles

\title{
I. Planteamiento del problema
}

El Derecho del Trabajo, en tanto disciplina jurídica, participa de un orden mayor en que la Constitución se alza como un garante de todo el sistema. En esta perspectiva, el ordenamiento laboral participa y se nutre de todos aqueIlos principios generales que informan el Derecho, cuestión que le permite ratificar su carácter esencialmente jurídico. Al formar parte de un sistema normativo mayor, inevitablemente las instituciones laborales se enfrentan a las tensiones derivadas de la aplicación de los principios generales y su relación con las particularidades de la disciplina.

Cuando la legislación laboral establece una regla específica de resolución, esta tensión obviamente disminuye pues el legislador ya ha resuelto la preeminencia de la regla particular a objeto de resolver la controversia. El problema aumenta, no obstante, cuando la ambigüedad y vaguedad de la regla laboral, o lisa y Ilanamente su inexistencia, dan cabida a la aplicación de principios generales en que se plantea la duda sobre la eventual desnaturalización de la especificidad laboral. Esto ocurre, por ejemplo, con la buena fe.

Desde hace algún tiempo, el ordenamiento chileno ha observado una importante controversia dogmática sobre el valor de este principio general como elemento de resolución de conflictos laborales. Y esta controversia ha estado precedida de una variada jurisprudencia que ha invocado a la buena fe para resolver casos difíciles, o bien para reafirmar la tesis de que el Derecho del Trabajo se encuentra acoplado al sistema jurídico general del cual no puede renegar si efectivamente pretende ser una disciplina jurídica. A tal nivel ha llegado esta controversia, que en algunos casos se ha llegado a proponer, incluso, que la buena fe no tendría cabida en el ámbito laboral ya que se trataría de una figura propia del Derecho Civil, cuya incorporación en el ámbito laboral desnaturalizaría al Derecho del Trabajo.

En el presente artículo se parte de la base que la buena fe constituye un principio general del Derecho y que, en tal condición, resulta aplicable a cada disciplina jurídica. Pero más allá de eso, la buena fe se encuentra incorporada en la propia normativa laboral y en la estructura propia del 
contrato de trabajo, y sus directrices son predicables tanto del trabajador como del empleador. De allí que el cumplimiento de las obligaciones de ambos contratantes, se encuentre imbuido de este principio.

\section{BUENA FE Y CONTRATO DE TRABAJO}

Aun cuando la sola evocación de la buena fe tiene una inconfundible vinculación con los conceptos jurídicos indeterminados ${ }^{1}$, lo cierto es que este principio encierra una interpretación amplia que lo convierte en un decisivo instrumento de integración de todo el ordenamiento legal ${ }^{2}$. En virtud de la buena fe, el sistema jurídico logra plasmar valores generales que modalizan la conducta de los contratantes e inspiran la aplicación de toda su normativa.

Sin perjuicio de que no existe un concepto unívoco de este principio, la buena fe se traduce en una obligación de las partes contratantes que les exige actuar rectamente, de forma honrada, sin intención de dañar u "oscurecer" las cláusulas acordadas, obligándose a observar una determinada actitud de respeto y lealtad en el tráfico jurídico, ya sea que se actúe en el ejercicio de un derecho como de una obligación ${ }^{3}$. En el fondo, se hace referencia a valores tradicionales y esenciales para el ordenamiento jurídico como son la confianza, la lealtad, la honradez o la rectitud ${ }^{4}$. Estos deberes son recíprocos y expresan un espíritu de colaboración y confianza aplicables a cualquier disciplina jurídica. ${ }^{5}$ Con ello, se impide a las partes actuar motivadas por un

1 Cfr., González Rodríguez, Manuel, "Bocetos jurídicos: la buena fe y la seguridad jurídica", AAMN, T. III, 1946, p. 327.

2 Cfr., por todos, De los Mozos, José Luis, El principio de la buena fe. Bosch, Barcelona 1965, pp. 123 y ss.; González Pérez, El principio general de la buena fe en el Derecho Administrativo, Civitas, Madrid 1983, pp. 19 y 20; López SANTA MARía, Jorge, Los contratos (Parte General), Editorial Jurídica de Chile, $1^{\text {a }}$ Edición, Santiago 1986, p. 288; y LASARTE, Carlos, "Sobre la integración del contrato: la buena fe en la contratación (en torno a la sentencia del T.S. de 27 de enero de 1977)", RDP, enero, p. 68.

3 Cfr., entre otros, CAPÓN FILAS, Rodolfo E., "El abuso del Derecho en relación al contrato de trabajo", Estudios de Derecho Individual de Trabajo en homenaje al profesor Mario L. Deveali. Heliasta S.R.L., Buenos Aires 1979, pp. 780 y ss.; Iruzubieta Fernández, Rafael, El abuso del Derecho y el fraude de ley en el Derecho del Trabajo. Colex, Madrid, 1989, pp. 35 y 36; y LASARTE, "Sobre la integración", cit. nota n. 2, p. 61. Vid., también, Escudero, J. F., Frigola, J.; Corbella, T., El principio de buena fe en el contrato de trabajo, Bosch, Barcelona 1996, pp. 23 y 24.

4 Vid. Gil y Gil, José Luis, Principio de la buena fe y poderes del empresario, Consejo Andaluz de Relaciones Laborales, Sevilla 2003, p. 116.

${ }^{5}$ Vid. FerreiRa Rubio, Delia Matilde, La buena fe. El principio general en el Derecho Civil, Montecorvo, Madrid 1984, p. 140. Cfr. además FueYo LANerI, Fernando, Instituciones de Derecho Civil moderno, Editorial Jurídica de Chile, $1^{\text {a }}$ edición, 1990, p. 144; y LASTRA LASTRA, José Manuel, "La buena fe en el trabajo: ¿un principio que se difumina?", Derecho y Conocimiento Volumen 3, p. 2. Sobre la aplicación del principios en otras áreas del Derecho vid. además SAinz Moreno, Fernando, "La buena fe en las relaciones de la administración con los administrados", RAP No 89, p. 297; y BOETTIGeR PHILIPPS, 
mero interés particular o exclusivo, que haga perder el sentido de utilidad común que debe informar a los actos jurídicos.

Las normas generales, así como las prohibiciones de fraude y abuso de derecho que se consignan en el Código del Trabajo, permiten afirmar que todo el ordenamiento laboral, y en particular el contrato de trabajo, se encuentran circunscritos necesariamente al requisito de la buena fe $\mathrm{e}^{6}$. Este carácter, que ha terminado primando como principio informador del Derecho, permite que los contratantes lleven a cabo sus propios actos en el entendido de que se trata de actuaciones válidas, tutelando mínimas normas de comportamiento que eviten la frustración del fin del contrato ${ }^{7}$.

Camila, "El principio de la buena fe en la jurisprudencia de la Contraloría General de la República en materia urbanista", AJ № 19, T. I, Año X, pp. 311 y ss. En el plano jurisprudencial, vid. sentencia de la Excma. Corte Suprema de 7 de octubre de 2004, RDJ, T. Cl, sección tercera (2004), p. 170. Para una tesis contraria a la existencia de un concepto unitario de buena fe, vid. Grodeau, Michel J., "Lealtad y buena fe contractual", $R C D I \mathrm{~N}^{\circ} 609$, p. 300.

${ }^{6}$ El principio de la buena fe tiene una especial relación con conceptos generales del derecho vinculado al fraude de ley, el abuso de derecho o la equidad. En todos estos casos existe una indudable finalidad correctora, de forma tal que los derechos se ejerzan regularmente, sin desviación ni abuso. Con todo, desde una perspectiva conceptual todas estas figuras son claramente diferenciables. En el primer caso, el fraude de ley hace referencia a la utilización de un precepto legal para alcanzar un resultado contrario al orden legal (cfr. por todos RUIz DE VeLASCO, José María, "La buena fe como principio rector del ordenamiento jurídico español en relación con las prohibiciones del fraude de ley y del abuso del derecho", RGLJ Año CXXV, № 6, pp. 537 y ss.). El fraude es un concepto técnico, cuya finalidad es eludir la aplicación de una norma operando al margen de todo criterio de reciprocidad. Esta idea de fraude de ley es distinta del principio de la buena fe. Ciertamente, quien actúa bajo el amparo del fraude termina realizando una conducta contraria a la buena fe; pero en rigor lo que sanciona el principio que comentamos es la realización de un comportamiento desleal y deshonesto, independientemente de si se ha tratado de utilizar una norma distinta (cfr. González, El principio, cit. nota n. 2, p. 27). En lo que respecta al abuso de derecho, sus vínculos con el principio de buena fe son más estrechos. En efecto, en ambos casos nos encontramos ante un límite en el ejercicio de los derechos. Tanto la figura del abuso como la invocación de la buena fe impiden sobrepasar los límites normales en el ejercicio de un derecho (cfr. Martínez CalcerRada, Luis, "La buena fe y el abuso del Derecho. Su respectiva caracterización como límites en el ejercicio de los derechos". RDP № 63, pp. 450 y ss. Vid. además Cattaneo, Giovanni, "Buonna FEDE objetiva e abuso del diritto", RTDPC Anno XXV № 3, 1971, pp. 634 y ss.; Grodeau, "Lealtad", cit. nota n. 5, pp. 308 y ss.; y Ruiz de Velasco, "La buena fe", cit. nota n. 6, pp. 550 y ss. A mayor abundamiento, FueYo LANERI, Fernando, El ejercicio abusivo del derecho, La Plata Revista del Colegio de Abogados, pp. 17 y ss.). Tanto es así que en países como Alemania, la regulación del abuso de derecho es vista como una concreción del principio de la buena fe (vid. WIEACKER, Franz, El principio general de la buena fe, traducción de Carro, José Luis, Civitas, Madrid, 1977, p. 59). Por último, también existen diferencias entre la buena fe y la equidad. Mientras la primera se aplica en el marco de la ejecución contractual, con los derechos y obligaciones que surgen del acto jurídico, la equidad se aplica en el plano estrictamente normativo. La equidad, por tanto, permite atenuar la aplicación de la norma en razón de circunstancias objetivas (cfr. GonzÁlez, "El principio general", cit. nota n. 2, p. 33; y De Los Mozos, El principio, cit. nota n. 2, pp. 75 y ss.).

7 Vid., Román de LA ToRre, María Dolores, Poder de Dirección y Contrato de Trabajo, Grapheus, $1^{\text {a }}$ Edición, Valladolid, 1992, p. 254. Vid., también, García VIÑA, Jordi, La buena fe en el contrato de trabajo, Consejo Económico Social, $1^{\text {a }}$ edición, Madrid, 2001, p. 44; AlMANSA PASTOR, José Manuel, "Los principios generales del Derecho en las fuentes normativas del Derecho del Trabajo", CCDT № 3, 1972, pp. 20 y 
Con todo, conviene recalcar que la buena fe aplicable a las relaciones de trabajo no es muy distinta de aquella que se aplica en el resto de las disciplinas jurídicas ${ }^{8}$. A fin de cuentas, la buena fe se alza como un principio general del Derecho, predicable de todo el sistema normativo, razón por la cual no debiera llegar a sostenerse que el Derecho del Trabajo constituye un estanco independiente de todo el ordenamiento. Lo que ocurre es que, en materia laboral, la buena fe adquiera una especial modalización de las conductas de los contratantes en atención a las mayores exigencias de trato correcto entre ellos ${ }^{9}$. No hay que olvidar que, al menos en el caso de trabajador, su vínculo es intuito personae, lo que deja en evidencia el cumplimiento de deberes en que el compromiso del deudor es más complejo que en otro tipo de contratos. Asimismo, en el ámbito de las relaciones laborales, los deberes de coordinación se encuentran en la base de las obligaciones contractuales, cuestión que obliga a acomodarse de forma más rigurosa a las exigencias de la buena $\mathrm{fe}^{10}$.

\section{La configuración general del principio de buena fe}

Existe consenso actualmente en el hecho de que la buena fe constituye un principio general del Derecho, aplicable a todas las ramas del sistema jurídico. Lo anterior resulta predicable no solo para las instituciones y normas del Derecho continental, sino que también ha tenido amplia vigencia en el ordenamiento anglosajón bajo la figura de la equity, alcanzándose de esta manera resultados similares a los que se logran en el Derecho continental mediante el expediente de la buena fe ${ }^{11}$.

ss.; y RodríGuez-Sañudo GutiérRez, Fermín, "La transgresión de la buena fe contractual como causa de despido". Cuestiones Actuales de Derecho del Trabajo. Estudios ofrecido por los catedráticos españoles de Derecho del Trabajo al profesor Manuel Alonso Olea. Centro de Publicaciones Ministerio de Trabajo y Seguridad Social, Madrid 1990, pp. 525 y ss. En el plano jurisprudencial, vid. Sentencia de la Excma. Corte Suprema de 24 de mayo de 2005, RDJ T. CII, sección tercera, 2005, p. 326; Sentencia de la Excma. Corte Suprema de 23 de noviembre de 2003, RDJ T. CIII, sección tercera, 2006, p. 918; y Sentencia de la Excma. Corte Suprema de 17 de marzo de 2003, RDJ T. C, sección tercera, 2003, p. 24.

${ }^{8}$ Cfr., LLuis NAvAS, Jaime, "El principio de buena fe en las relaciones laborales", RTL, Vol. 78, 1998, p. 625.

9 Cfr. Conde Marín, Emilia, La buena fe en el contrato de trabajo. La Ley, $1^{\text {a }}$ edición, Madrid 2007, p. 88. Vid. también Rodríguez-Piñero y Bravo-Ferrer, Miguel, "Poder de dirección y derecho contractual". El Poder de Dirección del empresario. Nuevas perspectivas. La Ley, $1^{\text {a }}$ edición, Madrid 2005, p. 18.

${ }^{10}$ Cfr. GIL y GIL, Principio, cit. nota n. 4, p. 196.

11 Históricamente, la buena fe se remonta al propio Derecho romano, el que utiliza la fides para informar la vida social, penetrando de esta manera en el orden jurídico a través de un elemento natural. A partir del ius Pentium, el Derecho romano objetiviza esta figura a través de la bona fides propiciando la corrección en el comportamiento mercantil. Aquí la buena fe no se fundamenta en un error, o en la existencia o inexistencia de un hecho, sino que en el parecer unánime de las personas razonables y honradas (el cual, por lo demás, se expresa en los usos sociales). La objetivización de la fides, entendida como lealtad a la palabra dada (y que se recoge en el adagio pacta sunt servanda), se expandió a 
Independientemente del hecho de si existe recepción concreta en una norma jurídica determinada, lo cierto es que no resultaría admisible restarle valor a este principio por la simple circunstancia de no estar positivizado. Los principios son una clase de norma jurídica diferenciada de las reglas de conducta, más allá de si son recogidos expresamente por el legislador. De allí que habrá que sostener que el principio de la buena fe informa al ordenamiento jurídico más allá de si existe o no una norma de carácter legal que lo reconozca como tal ${ }^{12}$.

La circunstancia de considerar a la buena fe como principio trae una serie de consecuencias prácticas ${ }^{13}$. En primer término, la buena fe actúa como fuente del Derecho en defecto de la ley y de la costumbre, exigién-

las relaciones de patronato y clientela e, incluso, entre patrono y liberto. En el ámbito contractual, las obligaciones de las partes obligaban a circunscribir las conductas no sólo a lo que indicaba el contrato, sino que, además, a las exigencias de la buena fe. De esta manera, al bonusvir podía exigírsele una conducta propia del hombre honesto en caso de surgir alguna controversia. La bona fides no estaba conformada exclusivamente por las directrices de una norma legal, sino que también se nutría de las elaboraciones doctrinales, de los usos y costumbres y del arbitrio judicial. Con posterioridad al Imperio romano, el concepto de buena fe se vio influenciado tanto por el Derecho canónico como por el iusmercatorum, el cual obligaba a respetar los valores de la confianza y la honradez. Mediante la vinculación con el Derecho canónico, la bonus fides se asoció con matices sicológicos y de conciencia, abriendo una clasificación del concepto que perdura hasta nuestros días. Durante el proceso de codificación, la buena fe se incorporó en los Códigos Civiles, fundamentalmente, en aquellos preceptos dedicados al cumplimiento y ejecución de las obligaciones. El Código de Napoleón, por ejemplo, incorporó la buena fe al momento de regular los efectos de las obligaciones (art. 1134) y señaló que los contratos obligaban no sólo a lo expresamente previsto en ellos, sino a todas las consecuencias que se derivan de la equidad, el uso o la ley, según la naturaleza de la obligación. La misma tendencia siguió el BGB alemán, en los artículos 157 y 242. Lo relevante, en el caso alemán, es que el sistema jurídico impuso la idea de que el ejercicio abusivo de un derecho era contrario al principio de la buena fe. De allí que, en el Derecho alemán, la buena fe (Treu und Glauben) se alce como un límite al ejercicio de los derechos. Sobre el particular, vid. entre otros Castresana, Amelia, Fides, bona Fides: un concepto para la creación del derecho. Tecnos, Madrid 1991, pp. 13 y ss.; De Los Mozos, "El principio", cit. nota n. 2, pp. 22 y ss.; Gil y Gil, Principio, cit. nota n. 4, pp. 25 y ss.; Dízz-PICAzo, Luis, La doctrina de los propios actos. Bosch, Barcelona 1963, pp. 21 y ss.; Guzmán Brito, Alejandro, "La buena fe en el Código Civil de Chile", RCHDVol. 29 № 1 (2002), pp. 11 y ss.; y TuHR, Andreas v., "La buena fe en el Derecho romano y en el Derecho actual", RDP No 146 (1925), pp. 23 y ss.

12 En rigor, la buena fe a secas es un concepto técnico-jurídico que se inserta en una multiplicidad de normas jurídicas para describir o delimitar un supuesto de hecho. Pero otra cosa distinta es el principio general de buena fe: "Aquí la buena fe no es ya un puro elemento de un supuesto de hecho normativo, sino que engendra una norma jurídica completa, que, además, se eleva a la categoría o al rango de un principio general del derecho: todas las personas, todos los miembros de una comunidad jurídica deben comportarse de buena fe en sus recíprocas relaciones". Vid., Dízz-PICAzo, Luis, prólogo a la obra de WIEACKER, Franz, El principio general de la buena fe. Traducción de José Luis Carro. Civitas, Madrid 1977, pp. 11 y 12. Con todo, habrá que reconocer que existe una cierta proliferación de términos que intentan reflejar una misma idea, sobre todo en el ámbito de las cláusulas generales de la buena fe: abuso de derecho, equidad, cláusulas generales de las leyes, preceptos en blanco, válvulas del ordenamiento, estándares, directivas, entre otras varias alternativas.

${ }_{13}$ Cfr. García, La buena fe, cit. nota n. 7, p. 63. 
dose una interpretación y aplicación normativa conforme a las directrices del principio. En sede laboral, la buena fe impondrá a los contratantes un conjunto de deberes y conductas que terminan limitando la autonomía de la voluntad y la discrecionalidad en el ejercicio de los derechos. Si la buena fe es un principio, éste impregna todas las fuentes del sistema jurídico y obliga a que los contratantes ajusten su acción a dicho principio.

La buena fe supone proteger una serie de relaciones jurídicas, en atención a razones de carácter moral o de tráfico social ${ }^{14}$. Con ello, la buena fe se convierte en un criterio ordenador de las relaciones jurídicas, modalizando el contrato de conformidad con las reglas de conducta socialmente consideradas como dignas de respeto ${ }^{15}$. En el ámbito laboral, la buena fe traerá aparejada la protección del contratante diligente y que actúa fundado en un proceder correcto, sin que exista fraude o dolo en su obrar. De este modo, la buena fe del contratante se traducirá en el hecho de que tanto su declaración o conducta, así como su voluntad, se ajustan no sólo a los cánones de la legalidad, sino que, también, a los de la justicia ${ }^{16}$. Esto explica el que la protección del ordenamiento se despliegue en toda su magnitud cuando el error en que se ha incurrido no sea irresponsable, cuando para llegar a la convicción se ha empleado la diligencia propia de una persona cuidadosa. Pero no puede considerarse engañado quien conoce y sabe la existencia de un fraude o de un abuso detrás de una determinada actuación o figura contractual; ni el ordenamiento jurídico podría amparar dicha situación, pues lo que se busca precisamente es evitar los subterfugios o actuaciones engañosas ${ }^{17}$.

\footnotetext{
14 Cfr., González, "Bocetos", cit. nota n. 1, p. 328. Cfr. también Gil y Gil, Principio, cit. nota n. 4, pp. 61 y siguientes: y GonzÁLEZ, El principio general, cit. nota n. 2, p. 19. En el plano jurisprudencial, vid. Sentencia de la Excma. Corte Suprema de 31 de julio de 1990, RDJ, T. LXXXVII, sección tercera, 1990, p. 91: "Las normas de honradez, inherentes a toda actividad humana, se deben entender incorporadas al contrato de trabajo, aun cuando no exista texto que lo imponga, dado que la honradez no puede quedar sujeta a la existencia de una disposición expresa que la establezca".

15 Vid., Montora, Alfredo, La buena fe en el Derecho del Trabajo. Tecnos, Madrid 2001, p. 17: "La buena fe opera, así, corrigiendo los excesos del individualismo jurídico, procurando dar a cada cual lo suyo y prohibiendo el daño a terceros".

16 Cfr., Herrero Nieto, Bernardino, La simulación y el fraude a la ley en el Derecho del Trabajo, Bosch, Barcelona 1958, p. 242. Vid. también Dieguez Cuervo, Gonzalo, La fidelidad del trabajador en LCT, Ediciones Universidad de Navarra, Pamplona 1969, p. 16.

17 Cfr., Fernández Gianottı, Enrique, "Fraude de derechos laborales", Relaciones Laborales T. I, Madrid 1991, p. 1199.
} 


\subsection{Los tipos de buena fe aplicables al contrato de trabajo: la buena fe objetiva y subjetiva}

Como es ampliamente sabido, la buena fe admite una doble clasificación en buena fe subjetiva y buena fe objetiva. La buena fe subjetiva -o de creencia $o$ ignorancia ${ }^{18}$ se vincula con un aspecto más bien sicológico, interno del sujeto, que permite purificar conductas impropias que, de otra forma, serían consideradas ilícitas. Cuando se actúa con buena fe subjetiva, el contratante cree estar realizando una conducta correcta, aun cuando ella es completamente irregular. Y su actuación equívoca se debe a un error excusable, a una simple ignorancia o bien a una apariencia engañosa. Su buena fe subjetiva, no obstante, sanea de alguna manera su responsabilidad. De allí la importancia que la ignorancia del sujeto sea excusable, ya que de otra forma la persona sería responsable del acto irregular.

Este tipo de buena fe se aplica en áreas generales del Derecho, básicamente en el ámbito de los derechos reales o en la doctrina del error ${ }^{19}$, pero deja al descubierto una falencia que para efectos laborales tiene bastante relevancia: prescinde de la valoración moral que externamente se pueda realizar sobre la conducta del sujeto. De esta manera, al reducirse al mero fuero interno, el parámetro de la buena fe subjetiva reduce su campo de acción y sólo permite justificar o entender el comportamiento de la persona desde su propia creencia cuestión que surte el efecto de "exonerar de la responsabilidad en que se hubiera incurrido en otro caso" ${ }^{\prime 2}$. De allí que la buena fe subjetiva exija analizar la creencia o ignorancia de no dañar un interés ajeno tutelado por el Derecho ${ }^{21}$.

Cada vez que el ordenamiento jurídico se refiere a una conducta, exigiendo que la misma sea ejecutada de buena fe, en el fondo se está haciendo referencia aisladamente a una creencia, o a un estado de conciencia, tal como ocurre con la buena fe subjetiva ${ }^{22}$. En el Derecho del Trabajo, las referencias a la buena fe subjetiva se producen fundamentalmente en materia de Derecho colectivo y

\footnotetext{
${ }_{18}$ Vid. Dízz-Picazo, "Prólogo", cit. nota n. 12, p. 14. Del mismo autor, La doctrina, cit. nota n. 11, pp. 134 y ss.

${ }_{19}$ Cfr. por todos Larenz, Kart, Derecho de Obligaciones, T. I. Versión española y notas de Jaime Santos Briz. Edersa, Madrid 1958, p. 144.

${ }^{20}$ Vid. Montora, La buena fe, cit. nota n. 15, p. 23.

${ }^{21}$ Cfr. De los Mozos, El principio, cit. nota n. 2, pp. 57 y 58. Y agrega: “(...) se trata de una conducta, o más bien de un acto, que de no mediar la buena fe, sería antijurídico o irregular". Vid. también López, Los contratos, cit. nota n. 2, p. 289: "(...) la buena fe subjetiva es una noción justificativa del error". A mayor abundamiento, vid. GÓmEz-ACEBO, F., "La buena y la mala fe: su encuadramiento en la teoría general del Derecho y su eficacia en el Código Civil", RDP No 36 (1952), pp. 109 y ss.

${ }^{22}$ Cfr. Ferreira, La buena fe, cit. nota n. 5, p. 149.
} 
de prohibición de prácticas desleales ${ }^{23}$; en la tipificación de ciertas causas de despido disciplinario ${ }^{24}$; en el otorgamiento y uso malicioso de certificados $^{25}$, en la sanción de simulaciones ilícitas ${ }^{26}$, o en los supuestos de apariencia jurídica ${ }^{27}$.

23 Vid a modo de ejemplo, el artículo 387, letra c) y el artículo 388, letra a), del Código del Trabajo. Sobre el particular, la jurisprudencia ha señalado que para tipificar la conducta como práctica desleal, resulta esencial la concurrencia de la mala fe: “(...) para que dichas actuaciones del empleador tengan el carácter de práctica desleal punible, deben haberse llevado a cabo con manifiesta mala fe y con la finalidad de obstruir el desarrollo regular de la negociación colectiva (...)". Sentencia de la Excma. Corte Suprema de 20 de junio de 2007, GJ № 324 (2007), pp. 267 y ss. En similar sentido, cfr. Sentencia de la lltma. Corte de Apelaciones de Santiago de 08 de septiembre de 2006, GJ № 315 (2006), p. 302; y Sentencia de la Iltma. Corte de Apelaciones de Santiago de 16 de agosto de 2006, G) № 314 (2006), p. 278.

${ }^{24}$ Cfr., artículo $160 \mathrm{~N}^{\circ} 6 \mathrm{CT}$.

${ }^{25}$ Cfr. artículo 509 del Código del Trabajo.

${ }^{26}$ Ese sería el caso del inciso primero del artículo 507 del Código del Trabajo: "Se sancionará con una multa (...) al empleador que simule la contratación de trabajadores a través de terceros (...)". El problema de este artículo es que su inciso tercero se desmarca de la intencionalidad y pone el acento en el resultado: "El que utilice cualquier subterfugio, ocultando, disfrazando o alterando su individualización o patrimonio y que tenga como resultado eludir el cumplimiento de las obligaciones laborales y provisionales" será sancionado con multa a beneficio fiscal. Y en su inciso tercero se agrega que quedan comprendidos dentro del concepto de subterfugio, cualquier alteración “(...) que signifiquen para los trabajadores disminución o pérdida de derechos laborales individuales o colectivos (....". Como se puede apreciar, los incisos segundo y tercero del artículo 507 terminan colocando en el centro de atención el resultado obtenido, más que la intención del agente. Consideraciones similares podrían efectuarse en relación con la norma del artículo 183-U del Código del Trabajo. En virtud de dicho precepto, los contratos de trabajo celebrados en supuestos distintos a aquellos que justifican la contratación de servicios transitorios, "o que tengan por objeto encubrir una relación de trabajo de carácter permanente con la usuaria", se entenderán celebrados en fraude a la ley. Por último, y en la misma línea, cabe destacar el artículo 152 bis G, consagrado en relación con el contrato de trabajo de los deportistas profesionales y de los trabajadores que desempeñan actividades conexas: "La entidad deportiva que utilizando cualquier subterfugio, oculte o simule beneficios o prestaciones laborales que tengan como causa el contrato de trabajo, será sancionada de conformidad a lo establecido en el artículo 152 bis L". Sin perjuicio de lo señalado, nada impide que el acto simulatorio no pueda derivar en una figura fraudulenta. Como se sabe, el efecto ilícito de un hecho jurídico no tiene por qué asimilarse, sin más, a una situación dolosa (cfr., CASTÁn ToBeÑas, José, Derecho Civil Español, Común y Foral, T. 1, Vol. I. Reus, reimpresión de la $14^{a}$ edición, Madrid 1987, p. 597). Lo cierto es que el criterio voluntarista o subjetivo ha cedido paso a la convicción de que igual se produce un abuso de Derecho o un fraude si el resultado de la acción termina siendo dañino o contrario a los preceptos imperativos del ordenamiento jurídico (cfr. por todos FueYo, Instituciones, cit. nota n. 5, pp. 359 y ss.). Por lo demás, en la mayor parte de los supuestos de fraude laboral queda en evidencia una voluntad maliciosa que se ampara en el subterfugio o aparato engañoso utilizado, generando una consecuencia antijurídica (cfr. entre otros Borrajo Dacruz, Efrén, "El abuso de derecho en el Contrato de Trabajo", RDT No 1, Año I, 1954, p. 2; e IRUZUBietA, El abuso, cit. nota n. 3, pp. 87, 93 y 216).

27 Algunos, no obstante, han circunscrito los problemas de apariencia dentro de un criterio mixto de la buena fe: "pues tanto se valora la postura psicológica del actuante como el juicio de valor aprobatorio de su actuación, según los módulos de normalidad" (vid. MARtínez, "La buena fe", cit. nota n. 6, p. 437. En esta línea, vid además Dí́z-PICAzo, La doctrina, cit. nota n. 11, pp. 134 y ss.; y LASARTE, "Sobre la integración", cit. nota n. 2, pp. 75 y 76). En todo caso, la práctica laboral ha dejado en evidencia que el principio de buena fe ha transitado simultáneamente con la doctrina de la apariencia jurídica, en cuya virtud el sujeto que pretenda ocupar una determinada posición de 
Pero en todos estos casos, la ley pone el énfasis en la creencia interna que el autor del acto tenía-sobre la corrección de su proceder-al momento de ejecutar su conducta. Como se ha dicho, la dificultad de este tópico radica en la falta de comparación que tiene dicha actuación con el entorno en el cual se aplica.

La buena fe objetiva soluciona las dificultades de calificación del fuero interno recién mencionadas. En este caso, se pone el acento en el comportamiento externo -leal y honrado- del sujeto contratante. Más que detenerse en un parámetro de conducta simplemente individual, la buena fe objetiva exige un examen comparativo entre el estándar de la norma jurídica y la acción del contratante. Si el sujeto desarrolla una conducta contraria al comportamiento

derecho debe ejecutar actos objetivos que induzcan a dicha conclusión. Es decir, que se prefigure externamente, y de modo verosímil, la figura que se pretende reclamar. Por lo general, el negocio simulado (acto bilateral) o doloso (acto unilateral) implica una declaración deliberadamente disconforme con la verdadera intención de los contratantes y destinada a engañar a terceras personas. (cfr., por todos, FerRARA, Francisco, La simulación de los negocios jurídicos, EDERSA, Madrid 1960, pp. 44 y 46). Dicha simulación permite, en el ámbito del Derecho del Trabajo, que se ejecute un acto externamente lícito y creíble -aunque no siempre con intención de dañar o falsear dolosamente-, pero que no se condice con la realidad. En virtud de ello, el "titular ficticio" realiza una serie de actos empresariales en nombre propio, aparentemente válidos (cfr., GARCÍA VIÑA, Jordi, "El abuso de derecho y fraude de ley: análisis jurisprudencial", $A L N^{\circ} 45,1993$, p. 833), pero que en verdad terminan teniendo una eficacia distorsionada. Ese sería el caso, por ejemplo, de un aparente empleador que se comporta como poseedor de una situación jurídica que no ostenta en Derecho, construyendo voluntariamente una ficción empleadora que induce en un legítimo error al trabajador, el cual cree que aquello que se manifiesta es efectivamente la realidad (Cfr., TALÓN MARTíneZ, Francisco T., "La apariencia jurídica", RJC, Año LI, Vol. LXIX, 1952, pp. 368 y 371). A la misma conclusión habría que llegar en el supuesto de que el empleador aparente actuara de buena fe, aunque en dicho caso más que una simulación, lo que existiría es un error, que igual logra proyectar una determinada apariencia jurídica. Piénsese, por ejemplo, en el caso del heredero aparente o putativo, o del mandatario que se le ha revocado el poder sin su conocimiento, quienes de buena fe creen tener la titularidad del negocio. Este se encuentra en posesión tranquila mientras no se deshaga la apariencia razonable. Por tanto, simulación y error son dos elementos que permiten configurar una externalidad determinada, provocando un divorcio entre la realidad y la formalidad. La apariencia, como se dijo, genera un actuar de acuerdo a lo que se presenta como auténtico hacia el exterior, provocando una conducta que, si bien no se condice con la verdadera naturaleza de las cosas, tiene su causa precisamente en una actitud creíble de la contraparte. Y esta sola circunstancia justifica, ciertamente, una protección por parte del ordenamiento, ya que no puede una persona, por acción u omisión, generar en otra la convicción legítima de un cierto estado de cosas para luego defraudar esa misma convicción. Como se ha señalado en la esfera del Derecho civil, pero aplicable al ámbito de las relaciones laborales, la teoría de la apariencia requiere una situación por la cual, quien ha confiado razonablemente en una determinada manifestación jurídica y se ha conducido conforme a ella, debe tener derecho a contar con tal manifestación aunque no se corresponda con la realidad (vid., De ÁnGel YAGǘz, Ricardo, Apariencia jurídica, posesión y publicidad inmobiliaria registral. Publicaciones Universidad de Deusto, Bilbao 1982, p. 14. Vid. también Peñailillo Arévalo, Daniel, "Titularidad real y titularidad aparente", $R D D U C \mathrm{~N}^{\circ}$ s. 219-220 Año LXXIV (2006), p. 10). En cuanto a la exigencia de que exista o no maquinación dolosa para la configuración de una apariencia fraudulenta, vid. además CASAS BaAmonde, María Emilia, "Irregularidad formal, fraude de ley y nulidad del despido disciplinario". Relaciones Laborales № 24 (1994), p. 88; y García Piqueras, Manuel, "La simulación en el contrato de trabajo", $A L \mathrm{~N}^{\circ} 21,1990$, pp. 242 y 247. 
normal y correcto de un hombre medio honrado, entonces su obrar es contrario a la buena fe objetiva ${ }^{28}$. De esta forma, la buena fe objetiva se construye como una regla de comportamiento, mínimamente normativizada, y no como un estado subjetivo de conciencia. Si la buena fe subjetiva se aprecia in concreto, "mediante averiguación de la convicción íntima y personal del sujeto implicado, (entonces) la buena fe objetiva se aprecia in abstracto" 29 .

Las reflexiones anteriores son plenamente aplicables al ámbito laboral. En el contexto del contrato de trabajo, el acento está colocado en la buena fe objetiva pues se le exige a los contratantes que ajusten sus conductas a una idea común de honradez y corrección ${ }^{30}$. Si la buena fe constituye una regla de gobierno de la discrecionalidad privada ${ }^{31}$, entonces lo lógico es que esa buena fe sea evaluada de acuerdo a parámetros objetivos. Y esa específica buena fe objetiva explica una disposición personal en la realización del contrato, una probidad en su ejecución y una "efectiva voluntad de correspondencia a la confianza ajena"32.

De esta manera, el ajuste de los comportamientos se hace, en primer lugar, de acuerdo a la norma jurídica que representa un mínimo ético socialmente aceptado; pero como tendremos oportunidad de señalar, no puede limitarse a una repetición, cuasi literal, de la norma. La buena fe objetiva impone mayores estándares de moralización de la conducta, un derecho más justo y progresivo ${ }^{33}$, razón por la cual la norma jurídica debe ser vista como un piso necesario, pero no exclusivo, de comportamiento de los contratantes ${ }^{34}$.

\subsection{Las funciones del principio de buena fe}

Como parte del sistema jurídico, muchas de las reglas y criterios que se aplican a otras disciplinas jurídicas también son relevantes para el Derecho del

\footnotetext{
${ }^{28}$ Cfr. Villaḉ́ Azevedo, Marco de Almeida, "Buena fe objetiva y los deberes de ella derivados". Tratado de la Buena Fe en el Derecho, T. II. Director Marcos M. Córdoba. La Ley, Buenos Aires 2004, p. 133.

${ }^{29}$ Vid. López Santa María, Los contratos, cit. nota n. 2, p. 292. Cfr. también Martins-Costa, Judith, "La buena fe objetiva y el cumplimiento de las obligaciones" Tratado de la Buena Fe en el Derecho, T. II. Director Marcos M. Córdoba. La Ley, Buenos Aires 2004, p. 99.

${ }^{30}$ Sobre la irrelevancia de la dualidad entre buena fe objetiva y subjetiva, vid. GARCíA VIÑA, La buena fe, cit. nota n. 7, p. 44: "En todo caso, esta dualidad es irrelevante en cuanto a su aplicación en el Derecho del Trabajo y de la Seguridad Social, ya que la mayoría de los supuestos han de ser incluidos en este concepto objetivo o normativo".

${ }^{31}$ Cfr. Gıl y GIL, José Luis, Autotutela privada y poder disciplinario en la empresa. Centro de Publicaciones del Ministerio de Justicia, Madrid 1994, p. 85.

32 Cfr., García Viña, La buena fe, cit. nota n. 7, p. 56.

33 Cfr. Montoya Melgar, La buena fe, cit. nota n. 15, p. 14.

${ }^{34}$ Vid en esta línea Sentencia de la Excma. Corte Suprema de 29 de octubre de 1991. RFM № 395 (1991), p. 606.
} 
Trabajo ${ }^{35}$. Todo este crisol de disciplinas se articula en torno a la Constitución y no podría pretenderse que, so pretexto de la especialidad y particularidad de esta rama del Derecho, el orden laboral estuviese ajeno a los principios generales que se estructuran a partir del sistema jurídico. Ello explica, en parte, la importancia que la buena fe tiene para el Derecho del Trabajo.

La buena fe en el plano laboral participa de, a lo menos, tres funciones básicas: (i) informadora; (ii) integradora, y (iii) correctora de derechos. La función informadora supone dotar de sentido y sistematizar un ordenamiento jurídico dado $^{36}$. De esta manera, se le infunde sentido y valor a las formulaciones jurídico-técnicas a objeto de que dicho ordenamiento sea más congruente con las exigencias de lealtad y honestidad que debe inspirar la conducta de los sujetos, respondiendo de esta manera a las exigencias del principio de responsabilidad negocia ${ }^{37}$. En razón de lo anterior, la buena fe permite sostener un vínculo entre el mundo jurídico-laboral y el sistema de valores socialmente aceptado. Esto evita que el Derecho sea concebido como una estructura neutra o de mera geometría social ${ }^{38}$, abriendo paso a una moralización del sistema jurídico ${ }^{39}$. A mayor abundamiento, esta función informadora del sistema jurídico, que ostenta la buena fe, permite concluir que el Derecho no es puro formalismo y que la aplicación de sus normas exige una conexión con el sistema de valores.

Paralelamente, la buena fe exhibe un carácter integrador de normas. Esta función resulta esencial en el contenido del negocio jurídico, toda vez que la

35 Vid., entre otras, Sentencia de la Excma. Corte Suprema de 20 de diciembre de 2006, RDJ, T. CIII (2006) sección tercera, p. 930: "Octavo: (...) la legislación laboral no puede considerarse en forma aislada del ordenamiento jurídico general, que regula las vinculaciones que generan los sujetos del derecho (...)". En esta misma línea, vid. Sentencia de la Excma. Corte Suprema de 24 de mayo de 2005, $R D J$ T. ClI, sección tercera, 2005, p. 326; y Sentencia de la Excma. Corte Suprema de 23 de noviembre de 2003, RDJ T. CIII, sección tercera, 2006, p. 918.

${ }^{36}$ Cfr. Ferreira Rubio, La buena fe, cit. nota n. 5, p. 173.

${ }^{37}$ Vid. por todas Sentencia de la Excma. Corte Suprema de 04 de abril de 2006, GJ № 310 (2006), p. 242: "El principio de la buena fe supone una posición de honestidad y honradez en el comercio en cuanto lleva implícita la plena conciencia de no engañar, ni perjudicar, ni dañar. Se trata, pues, de un principio que debe ser tenido en cuenta para la ejecución legal de todos los derechos y obligaciones que las partes adquieren como consecuencia del contrato de trabajo".

${ }^{38}$ Cfr. Conde Marín, La buena fe, cit. nota n. 9, p. 59.

${ }^{39}$ Vid. por todos Ferreira Rubio, La buena fe, cit. nota n. 5, p. 116: “(...) puede afirmarse que la mayoría de los autores reconoce que la buena fe es un punto de contacto entre el orden jurídico y el ético"; Carretero Sánchez, Santiago, "Un reducto para la libertad del juez: la doctrina de los actos propios y la buena fe", $A D H$ Vol. 4, 2003, p. 21: "En este sentido, se ha insistido en que la buena fe introduce en el Ordenamiento jurídico al Derecho con la moral social media"; y GARCía VIÑA, La buena fe, cit. nota n. 7, p. 20: "(la buena fe) Tiene, por tanto, la función de enlace entre la ética social vigente y el Derecho". En el plano jurisprudencial, vid. además Sentencia de la Iltma. Corte de Apelaciones de Concepción de 14 de agosto de 2002, GJ № 266, (2002), p. 204; y Sentencia de la Excma. Corte Suprema de 08 de enero de 1973, RDJ T. LXX, sección primera (1973), p. 3. 
voluntad de los contratantes -al igual que en el caso del legislador- es incapaz de prever todas las posibilidades que se derivan del acto jurídico ${ }^{40}$. A diferencia de lo que señala el positivismo ideológico, los principios generales del Derecho, y entre ellos la buena fe, permiten completar y rellenar los vacíos de la legislación o del acuerdo contractual, cerrando el sistema legal ${ }^{41}$. Lo anterior asegura que el ordenamiento jurídico sea visto como un sistema completo, pleno y $\sin$ fisuras ${ }^{42}$. En el caso particular del contrato de trabajo, la buena fe termina creando deberes y obligaciones que son claramente apreciables desde una perspectiva objetiva de la misma. Dicho de otra manera, los deberes de corrección y honradez, tan propios de una buena fe objetiva, se integran en la relación jurídico-laboral llenando las lagunas y los vacíos dejados por las partes contratantes. Dentro de este esquema, la invocación de la buena fe permitirá proteger la confianza general (base del tráfico jurídico), ${ }^{43}$ interpretar los puntos oscuros $^{44}$, fijar el contenido de la declaración de voluntad y resolver las dificultades de aplicación de los acuerdos contractuales. Y esta función termina siendo una consecuencia natural del carácter que tiene la buena fe como principio general del Derecho ${ }^{45}$.

Por último, la buena fe tiene una finalidad esencialmente correctora y limitativa de derechos. Ante el ordenamiento jurídico no existen derechos absolutos ni libertades abusivas, por tanto resulta natural concluir que la buena fe constituye una herramienta de corrección en el ejercicio de los derechos subjetivos. Dicha corrección se expresará, por ejemplo, en el reconocimiento de una responsabilidad derivada del injusto receso de las tratativas, en el quiebre de la confianza legítima o en el ejercicio contradictorio de una posición jurídica, en el abuso de la nulidad por

${ }^{40}$ Cfr. Larenz, Derecho, cit. nota n. 19, T. I, p. 117. En igual sentido, Grodeau, "Lealtad", cit. nota n. 5, p. 336.

${ }^{41}$ Cfr. Gil y Gil, Principio, cit. nota n. 4, p. 137. Vid. también Carretero Sánchez, "Un reducto", cit. nota n. 39, pp. 33 y 34.

${ }^{42}$ Cfr. Conde Marín, La buena fe, cit. nota n. 9, p. 67.

${ }^{43}$ Cfr. entre otros González Pérez, El principio general, cit. nota n. 2, p. 34, y Sainz Moreno, "La buena fe", cit. nota n. 5, p. 309.

${ }^{44}$ Cfr. De los Mozos, El principio, cit. nota n. 2, cit., pp. 34 y ss.

${ }^{45}$ Cfr. Sentencia de la Excma. Corte Suprema de 11 de mayo de 1992, RDJ T. LXXXIX, sección primera (1992), p. 46. 


\title{
motivos formales ${ }^{46}$; en la anulación de actos abusivos ${ }^{47}$ en la prohibición del poder formativo de resolución si el cumplimiento fue sustancial, en la aplicación de la teoría de los actos propios (Venire contra factum proprium) ${ }^{48}$, en la prohibi-
}

\begin{abstract}
${ }^{46}$ La lógica que subyace en esta figura es que todo aquel que voluntariamente ha cumplido un negocio jurídico ineficaz por defectos formales, no puede ejercer con posterioridad la acción de nulidad. La aceptación de ese cumplimiento no puede ser puesto en contradicción alegando la ineficacia del negocio (cfr. Dízz-Picazo, La doctrina, cit. nota n. 11, p. 88. Vid. también Larenz, Derecho, cit. nota n. 19, T. I, p. 159). Algunas referencias de esta herramienta de corrección pueden encontrarse en la Sentencia de la Excma. Corte Suprema de 30 de mayo de 2006, RDJ T.CIII, sección tercera (2006), pp. 296 y ss. En la causa, los demandantes habían reconocido la suscripción de finiquitos con cláusulas de renuncia de acciones. No obstante, como dichos finiquitos no tenían las formalidades exigidas por el artículo 177 CT, la Corte de Apelaciones de Chillán les había restado valor como mecanismo liberatorio. Los finiquitos en cuestión no estipulaban una renuncia al estilo del artículo $159 \mathrm{~N}^{\circ} 2 \mathrm{CT}$, sino que se limitaban a establecer una renuncia genérica de acciones en razón de un contrato ya extinguido. Dejando sin efecto el fallo de segunda instancia, la Corte Suprema casó la sentencia por considerar que en la especie se habían infringido los artículos 12 del Código Civil y $5^{\circ}$ del Código del Trabajo: "Los instrumentos en los que consta la renuncia a la acción han sido reconocidos por los actores en la diligencia de absolución de posiciones, en los que declaran haber concurrido libre y voluntariamente a otorgar dichos instrumentos, aunque agregan que no los leyeron, lo que no aparece verosímil al tenor de los hechos; de toda lógica resulta, entonces, concluir la validez de la renuncia de la acción ejercida". Y agrega: "Resulta útil también para dilucidar el tema, recurrir al Principio de la Primacía de la Realidad, conforme al cual las cosas son lo que son y no lo que las partes pretenden, y a la denominada Teoría de los Actos propios, basada en la noción que a nadie le es lícito ir en contra de sus propios actos anteriores que expresan su voluntad y definen su posición jurídica en una materia determinada y que se funda, en último término, en el principio más general de la buena fe, la que ciertamente tiene plena cabida en el ámbito de que se trata". Un criterio similar puede consultarse en la Sentencia de la Excma. Corte Suprema de 24 de mayo de 2005, RDJ T. CII, sección tercera (2005), pp. 326 y ss. En este caso, la actora también le negaba validez a los finiquitos pues no habían sido ratificados ante la autoridad administrativa. La Corte, no obstante, invocando la doctrina de los actos propios y el principio de la primacía de la realidad, rechazó la pretensión de la demandante, toda vez que los instrumentos cuestionados habían sido redactados por ella misma "por ser la encargada de esa labor en la empresa demandada". Otro caso relevante se encuentra en una Sentencia de la Excma. Corte Suprema que, fundada en el principio de la buena fe, resolvió rechazar la demanda de un trabajador que era, al mismo tiempo, gerente general, socio y director de la empresa demandada: "(...) se trata de un demandante que ostenta al unísono, las calidades de trabajador y empleador, es decir, sobre él recaía la obligación de escriturar, en la forma pertinente, su contrato de trabajo y al no hacerlo, en su favor, no pueden presumirse como estipulaciones del convenio las que él mismo declara, de manera que la presunción analizada (art. $9^{\circ}$ ) no recibe aplicación en este caso" (Sentencia de la Excma. Corte Suprema de 17 de marzo de 2003, $R D J T$. C, sección tercera (2003), pp. 24 y ss.). Con igual orientación, vid. Sentencia de la lltma. Corte de Apelaciones de Santiago de 08 de mayo de 2003, GJ No 275 (2003), p. 270: "Carece de importancia que la renuncia del trabajador no haya sido firmada ante alguno de los personeros que señala el artículo 177 del Código del Trabajo si quien la invoca es el propio trabajador en su demanda (...). Importa infracción al principio de buena fe la circunstancia de haber reconocido el actor que firmó su renuncia a sabiendas que, por faltarle exigencias formales del artículo 177 del Código del Trabajo, ésta carecería de eficacia, inhabilitándolo por consiguiente para censurar, en el actual juicio, la ineficacia de esta conducta".
\end{abstract}

47 Cfr. Larenz, Derecho, cit. nota n. 19, T. I, p. 150.

${ }^{48}$ La jurisprudencia ha venido utilizando, en materia de calificación del vínculo contractual, la doctrina de los actos propios. Como se sabe, esta teoría parte de la base que una facultad o poder es inadmisible cuando con él la persona se pone en contradicción con el sentido que había que dar a su conducta anterior (cfr. Gıl y Gil, Principio, cit. nota n. 4, p. 260). En estos casos, más que prohibir la mala fe, lo que se busca es proteger la seguridad del tráfico jurídico. Incluso, la jurisprudencia ha sostenido que 
"Vigencia del principio de la buena fe en el derecho del trabajo chileno"

\section{ción de invocar abusivamente la excepción de contrato no cumplido, en accionar judicialmente para exigir algo que el mismo demandante debe restituir por otro}

esta teoría se aplica en materia laboral, "al margen que, ni aun a pretexto del sello tuitivo del Derecho Laboral puede admitirse un enriquecimiento sin causa por parte del trabajador, merced a una acción que contradice sus actuaciones anteriores en la materia" (cfr. Sentencia de la Excma. Corte Suprema de 29 de marzo de 2005, RDJ T. CII, sección tercera (2005), pp. 288 y ss.). Ejemplos de la invocación de esta doctrina en materia de calificación contractual se encuentran, entre otros, en la Sentencia de la Excma. Corte Suprema de 20 de diciembre de 2006, RDJ T. CIII, sección tercera (2006), pp. 930 y siguientes: "Octavo: Que, además de lo ya relacionado, resulta útil recurrir a la denominada Teoría de los Actos Propios, basada en la noción que a nadie le es lícito ir contra sus propios actos anteriores que expresan la voluntad del sujeto y definen su posición jurídica en una materia determinada y que se funda, en último término, en el principio más general de la buena fe, la que, ciertamente, tiene plena cabida en el ámbito laboral de que se trata, pues como reiteradamente lo ha decidido esta Corte, la legislación laboral no puede considerarse en forma aislada del ordenamiento jurídico general, que regula las vinculaciones que generan los sujetos del derecho y que, en el caso, se ha traducido en la aceptación por parte del demandante de la existencia de una relación de naturaleza civil con sus respectivas consecuencias, durante más de quince años, sin haber formulado reclamo alguno en tal sentido. Noveno: Que, conforme a lo que se ha anotado en el motivo anterior resulta claro que se ha quebrantado también el artículo 1546 del Código Civil, norma en la cual se establece el principio de la buena fe contractual, la que debe primar en la ejecución de los contratos, por cuanto, no obstante que el actor definió su posición jurídica en la vinculación con la demandada en los términos señalados, ahora desconoce esa definición, pretendiendo obtener beneficios improcedentes y que derivarían de una relación de naturaleza distinta a la aceptada y fijada por los contratantes"; en la Sentencia de la Iltma. Corte de Apelaciones de Concepción de 21 de junio de 2007, GJ № 326, (2007), pp. 313 y siguientes: "No resulta lógico que el actor solicite indemnización por años de servicios de 29 meses, si durante 29 años ha recibido por la naturaleza de sus servicios prestados (que no constituyen relación laboral) honorarios, percibiendo la devolución de los impuestos retenidos por todo ese tiempo. Por el contrario (...) (no resulta) aceptable de acuerdo al principio de la buena fe, atribuirle, después de 29 años una calificación jurídica distinta". Otros fallos semejantes, pueden consultarse en: Sentencia de la Excma. Corte Suprema de 25 de enero de 2007, GJ 319, (2007), p. 314; Sentencia de la Excma. Corte Suprema de 04 de abril de 2006, GJ N 310 (2006), p. 242; Sentencia de la Excma. Corte Suprema de 29 de diciembre de 2005, GJ № 308 (2006), p. 158; Sentencia de la Iltma. Corte de Apelaciones de Santiago de 10 de julio de 2003, GJ № 277 (2003), p. 273; Sentencia de la lltma. Corte de Apelaciones de Concepción de 14 de agosto de 2002, GJ № 266 (2002), p. 204. La doctrina también ha servido para restarle validez a aquellos casos en que existe un uso sorpresivo o errático del poder disciplinario. Por ejemplo, cuando se pretende aplicar una sanción luego de un cierto período de tolerancia ante la falta reprochada. También se ha utilizado para prohibir el cambio de causal de despido que esgrime el empleador al momento de enviar la correspondiente carta aviso. En diversos fallos, la jurisprudencia ha señalado que las causales invocadas por el empleador en su carta fijan la cuestión controvertida, sin que sea admisible una modificación de la causal extintiva por hechos posteriores. La doctrina en comento también tiene aplicación en materia procesal: por ejemplo, en aquellos casos en que el litigante no puede reclamar por un vicio de procedimiento que conocía o debió conocer por negligencia culpable (cfr. artículo 429, inciso final, CT), o bien cada vez que la conducta del litigante en el proceso termine contradiciendo una conducta procesal o extra-procesal que no sea la concertación de un avenimiento o pacto. Sobre la doctrina de los actos propios, vid. entre otros muchos Dízz-PICAzo, La doctrina, cit. nota n. 11, pp. 145 y ss.; Carretero Sánchez, "Un reducto", cit. nota n. 39, p. 31; Grodeau, "Lealtad", cit. nota n. 5, pp. 310 y ss.; FUeYo LANerI, Instituciones, cit. nota n. 5, pp. 307 y ss.; WieACKeR, El principio, cit. nota n. 6, pp. 60 y ss.; AlCAínO TORRES, Rodrigo, "La responsabilidad por el acto propio y su incorporación en el Derecho Civil chileno". TDD Año XIX Nos. 1 y 2 (2004), pp. 111 y ss. Una posición contraria a la aplicación de esta doctrina en el ámbito laboral, puede consultarse en CAAmAÑo Rojo, Eduardo, "Análisis crítico sobre la aplicación de la doctrina de los actos propios en materia laboral", RDPUCV Vol. XXXII, semestre I (2009), p. 261. 
motivo ${ }^{49}$; o bien cuando se impide la exigibilidad de un derecho si el titular permaneció inerte por largo tiempo, generando en la contraparte la expectativa legítima de que el mismo no sería ejercido (el retraso desleal del Derecho alemán) ${ }^{50}$, entre

\begin{abstract}
${ }^{49}$ Esta lógica ha sido expresamente aceptada por la jurisprudencia al validar los descuentos efectuados por el empleador en el acto del finiquito, por deudas que el trabajador mantenía con éste. Según la jurisprudencia, aceptar un criterio distinto (en orden a prohibir los descuentos) supondría ratificar un enriquecimiento sin causa por parte del trabajador demandante, provocando de paso un empobrecimiento en el demandado. Sobre el particular, cfr. por todas Sentencia de la Excma. Corte Suprema de
\end{abstract} de 22 de mayo de 2001, RDJ T. XCVIII, sección tercera (2001), pp. 90 y ss.

${ }^{50}$ El retraso desleal (Verwirkung) constituye una creación de la doctrina alemana que se sustenta en la protección de la confianza (cfr. por todos WIEACKER, El principio, cit. nota n. 6, pp. 66 y ss.). Se trata de un caso especial de abuso de derecho que deja en evidencia un retraso desleal en el ejercicio de una atribución. Si el titular de un derecho ha tenido una conducta omisiva durante mucho tiempo, el adversario de la pretensión puede esperar objetivamente que ya no se ejercitará el derecho. "La 'Verwirkung' se produce cualquiera que hayan sido las causas del retardo y de la inactividad, incluso aunque el titular no haya tenido conocimiento de que la pretensión le asistía" (cfr. Dí́z-PICAzo, La doctrina, cit. nota n. 11, p. 95). En el ámbito laboral, la figura ha sido profusamente ocupada para sancionar supuestos de demora en la extinción de los contratos de trabajo. Como se ha señalado doctrinariamente: "(...) un retraso en la decisión de despedir crea la confianza de que no se ha tenido en cuenta la falta; es, pues, contrario a la buena fe valerse de una causa antigua para despedir al trabajador" (vid. GIL y GIL, José Luis, "La buena fe en el contrato de trabajo", RTSS octubre, (1996), p. 34). Más aún, en países como Italia, se ha hecho uso de la denominada teoría de la inmediatez, como argumentación frente a la inactividad del empleador (cfr. artículo $7^{\circ}$ del Estatuto de los Trabajadores italiano). En otros ordenamientos comparados, no obstante, el retraso desleal ha sido especialmente incorporado dentro de la legislación laboral. Así ocurre, por ejemplo, en el Código del Trabajo francés, cuyo artículo L-122-44 estableció un plazo de dos meses -desde el momento en que el empleador tomó conocimiento del incumplimiento- para que se inicie un procedimiento disciplinario. Con todo, para la aplicación de esta figura se han exigido doctrinariamente a lo menos la concurrencia de tres requisitos: (i) Una omisión en el ejercicio del derecho; (ii) El transcurso de un cierto período de tiempo, y (iii) Que el ejercicio posterior aparezca como desleal o intolerable para el adversario (cfr. por todos Gil y GIL, "La buena fe", cit. nota n. 50, p. 33). En Chile, la figura del retraso desleal ha sido especialmente utilizada por la jurisprudencia en los casos de extinción del contrato de trabajo. Así ocurrió, por ejemplo, en la Sentencia de la Iltma. Corte de Apelaciones de Santiago de 10 de agosto de 1988, en que el órgano jurisdiccional dispuso que el "transcurso de un término más que razonable sin que el empleador comunique al trabajador la terminación de su contrato de trabajo con indicación de los hechos y de causal de caducidad que ellos constituyen, revela la existencia de tolerancia o perdón respecto de la conducta del trabajador". (RDJ, T. LXXXV, sección tercera (1988), p. 136. Sobre aplicación jurisprudencial de la doctrina del perdón de la causal, vid. también Sentencia de la Excma. Corte Suprema de 29 de diciembre de 2005, GJ № 308 (2006), p. 158. Un reconocimiento indirecto a la misma figura, puede consultarse en la Sentencia de la Iltma. Corte de Apelaciones de Santiago de 12 de agosto de 1986, RDJ, T LXXXIII, sección tercera (1986), p. 121). Si el empleador no ejerce su derecho en la oportunidad correspondiente entonces deberá entenderse que perdió la posibilidad de invocar posteriormente las acciones respectivas (cfr. Sentencia de la Iltma. Corte de Apelaciones de Santiago de 27 de octubre de 1986. GJ № 7 (1986), p. 80). Y ello no es más que una exigencia de seguridad jurídica para el trabajador, quien no puede estar indefinidamente inmerso bajo la posibilidad de ser sancionado en cualquier momento por infracciones cometidas en un pasado sin límite de tiempo. La buena fe exige que el empleador haga uso de su derecho al despido por causa disciplinaria tan pronto conozca los hechos. Su omisión crea la confianza de que la falta no ha sido tomada en consideración. En síntesis, si el empleador abusara extemporáneamente de esta causal de extinción, simplemente se estaría contraviniendo el principio general de buena fe que debe inspirar en el ámbito de las relaciones 
otras varias alternativas ${ }^{51}$. Lo que ocurre es que con la aplicación de este principio, se pretende superar una lógica meramente formal y avanzar hacia un estadio en que la conducta de los contratantes se ajuste con la idea de lo justo y razonable. Por cierto, esto no implica que las partes tengan que ejecutar deberes extraordinarios o distintos de aquellos que les imponen el contrato o la normativa vigente. Simplemente, lo que se busca es que el actuar del trabajador y del empleador tenga como elemento modalizador criterios de honradez, lealtad y colaboración.

\section{La buena fe aplicable a las relaciones de trabajo}

Si la disciplina laboral participa de un sistema jurídico mayor, entonces las directrices de la buena fe que se aplican en el Derecho del Trabajo no pueden ser demasiado distintas de aquellas que se predican de todo el ordenamiento jurídico ${ }^{52}$.

La circunstancia de que la buena fe tenga plena cabida en el orden laboral, no puede hacer olvidar las particularidades propias de esta disciplina

laborales (cfr. Gil y Gil, Autotutela, cit. nota n. 31, pp. 132 y 133. Vid. del mismo autor, Principio, cit., pp. 265 y ss.). Con todo, cabe advertir que la propia jurisprudencia ha señalado que "(...) el perdón de la causal no tiene lugar, en general, cuando se trata de infracciones. cometidas por el empleador en perjuicio del trabajador y respecto de las cuales el dependiente haya dejado transcurrir un lapso sin reclamar en contra de ellas" (Sentencia de la Excma. Corte Suprema de 29 de marzo de 2005. RDJ T. Ch, sección tercera (2005), pp. 288 y ss.). De igual forma, la Verwirkung no debe ser confundida con la prescripción extintiva o con la renuncia tácita. En el primer caso, el ejercicio retrasado de un derecho, aún no prescrito, puede perfectamente ser considerado como contrario a la buena fe por permitir precisamente el retraso. Por lo demás, en la prescripción el transcurso del tiempo está perfectamente delimitado, cuestión que no ocurre en el retraso desleal en que el tiempo es indeterminado y debe ser calificado por el órgano jurisdiccional. En cuanto a las diferencias con la renuncia tácita, ésta sólo puede ser invocada cuando existe una declaración de voluntad tácitamente emitida. Lo anterior es especialmente relevante en materia laboral debido al carácter irrenunciable de los derechos (cfr. artículo $5^{\circ} \mathrm{CT}$ ). En esta perspectiva, la irrenunciabilidad del derecho no excluye la inadmisibilidad de su ejercicio fundado en la Verwirkung. Sobre la doctrina del retraso desleal, vid. por todos Díez-PICAzo, La doctrina, cit. nota n. 11, pp. 93 y ss.; y LaRenz, Derecho, cit. nota n. 19, T. I, p. 151.

${ }^{51}$ Vid. Martins-Costa, "La buena fe", cit. nota n. 29, pp. 103, 112 y 113. Cfr. también Gil y Gil, Principio, cit. nota n. 4, p. 121.

${ }^{52}$ Vid. por todas Sentencia de la Iltma. Corte de Apelaciones de Concepción de 14 de agosto de 2002, GJ № 266 (2002), pp. 204 y siguientes: "7º.- Que el principio de la buena fe se encuentra por encima de muchos otros, porque abarca el área completa del Derecho, cualquiera que sea la rama y se trate tanto del derecho privado como del público. Además, su jerarquía superior se repite al observarse que varias figuras importantes, como el ejercicio abusivo de derechos, el fraude a la ley, la causa ilícita, la doctrina de los actos propios, se nutren con el elemento estructural de la buena fe, o, lo que es igual, con la idea contraria de la mala fe, fraude, dolo, engaño, etc., que las figuras nombradas como efecto rechazan"; y Sentencia de la Iltma. Corte de Apelaciones de Santiago de 05 de junio de 1985, RDJ T. LXXXII, sección tercera (1985), p. 123: "El contrato (...) debe ejecutarse de buena fe, de tal suerte que ellas (las partes) deben someterse al contrato y, en ningún caso, prevalerse del propio dolo". En el ámbito doctrinal, vid. por todos Fuero Lanerı, Instituciones, cit. nota n. 5, pp. 139 y ss. 
que en la práctica obligan a tener en cuenta las mayores exigencias de trato correcto y leal que inevitablemente deben existir entre los sujetos de un contrato de trabajo ${ }^{53}$. Debido a la propia naturaleza de la relación jurídicolaboral, con un fuerte compromiso personal y con claras invocaciones al principio de confianza (Vertravensgrundsatz), todo indica que las relaciones jurídicas de trabajo están imbuidas por un particular requerimiento de honradez y corrección en el actuar de los contratantes ${ }^{54}$. No hay que olvidar que uno de los elementos centrales de la buena fe es el deber de no defraudar la confianza de la contraparte ${ }^{55}$. Lo anterior en caso alguno puede llevar a desconocer la idea preliminar de que el Derecho del Trabajo es una disciplina jurídica que se rige por los mismos principios generales del Derecho.

La conclusión antedicha ha venido precedida de una larga evolución de los conceptos de fidelidad, lealtad y buena fe. Dicha evolución ha supuesto desterrar aquellas concepciones corporativistas que fundadas en las teorías de Otto von Gierke pregonaban una confusión entre buena fe y exigencias de fidelidad que iban más allá del ámbito contractual, llegándose incluso a términos cuasi feudales ${ }^{56}$. En el fondo, estas doctrinas partían de la base que la fidelidad no podía asimilarse sin más al marco de la buena fe, sino que se requería algo más, traspasando las obligaciones del trabajador más allá de los límites de la propia buena $\mathrm{fe}^{57}$. Por cierto, estos criterios implicaban ampliar los poderes del empleador concibiendo las obligaciones del traba-

\footnotetext{
53 Cfr. García Viña, La buena fe, cit. nota n. 7, p. 46: "Esta regla de conducta (...) se fundamenta en una idea ética que obliga a comportarse leal y honestamente con la otra parte, obligando a ejercitar el derecho subjetivo de acuerdo con la confianza depositada por la otra parte y con su finalidad objetiva o económico social". En igual sentido, Díez-PICAzo, La doctrina, cit. nota n. 11, p. 141: "El ejercicio de un derecho subjetivo es contrario a la buena fe no sólo cuando no se utiliza para la finalidad objetiva o función económica o social para la cual ha sido atribuido a su titular, sino también cuando se ejercita de una manera o en unas circunstancias que lo hacen desleal, según las reglas que la conciencia impone en el tráfico jurídico".

${ }^{54}$ Vid. en esta línea Sentencia de la lltma. Corte de Apelaciones de Santiago de 20 de agosto de 2007. $N^{\circ}$ de Ingreso Corte 20-2007 (aun sin publicar al momento de redactar estas líneas): "El contrato de trabajo se encuentra gobernado por principios que ambas partes deben respetar, entre ellos el deber de fidelidad y lealtad, que implica el desarrollo de confianzas mutuas, generadas a partir del cumplimiento de buena fe de las obligaciones que cada parte asume" (voto disidente).

${ }_{55}$ Cfr., Montoya Melgar, La buena fe, cit. nota n. 15, p. 67. Cfr. también García Viña, La buena fe, cit. nota n. 7, p. 47; y LLuis NAVAS, "El principio", cit. nota n. 8, p. 623.

${ }^{56}$ Vid. por todos Von Gierke, Otto, Las raíces del contrato de servicios, Civitas, reimpresión de la $1^{\text {a }}$ edición, Madrid 1989, pp. 11 y ss. Vid., también, Montora MelGar, La buena fe, cit. nota n. 15, p. 32: “(...) la implicancia de la persona en la relación laboral no significa hoy su lealtad absoluta o su vasallaje (...)".

57 Cfr. GIL y GIL, Principio, cit. nota n. 4, pp. 187 y 189. Vid. también y entre otros EsCudero, Frigola y Corbella, El principio, cit. nota n. 3, p. 41; Baylos Grau, Antonio, Derecho del Trabajo: modelo para armar, Trotta, Madrid 1991, pp. 23 y ss.; Fernández López, María Fernanda, "La transgresión de la buena fe contractual". RPS No 138 (1983), p. 223.
} 
jador como parte de una relación unidireccional. Todo esto ha obligado a que los antiguos requerimientos de fidelidad sean reconducidos hacia los deberes de corrección y buena fe que se exige a todo contratante de acuerdo a las reglas generales del ordenamiento jurídico ${ }^{58}$.

En esta perspectiva, la evolución del Derecho del Trabajo nos Ileva a sostener que la buena fe se relaciona con la lealtad contractual, recíprocamente establecida, y cuyo fundamento arranca de la propia Constitución ${ }^{59}$. Es en el propio Código Político donde se encuentran los criterios de razonabilidad, cooperación, proporcionalidad y respeto a los derechos fundamentales, los cuales se instalan en la base del contenido de este principio. Es desde la propia Carta Fundamental de donde se derivan los deberes de moderación en la percepción del propio interés y los instrumentos de información, cooperación, adaptación, transparencia y diálogo entre trabajador y empleador ${ }^{60}$.

Con todo, habrá que tener presente que en materia laboral, la aplicación de la buena fe se ha ido produciendo caso a caso, cuestión que dificulta el establecimiento de formulaciones generales ${ }^{61}$. Por el contrario, y de la mano de la jurisprudencia, la concreción de este principio ha estado imbuida

\footnotetext{
${ }^{58}$ Vid. González Ortega, Santiago, "La fidelidad a la empresa como obligación del trabajador: sentido y alcance en el marco de la relación laboral", RPS № 118 (1978), p. 249. Cfr. también y entre otros Hueck, Alfred, y Nipperdey, H. C., Compendio de Derecho del Trabajo. Revista de Derecho Privado, Madrid 1963, pp. 119 y ss.; Baylos Grau, Antonio,"El deber de lealtad del trabajador a la empresa. Obligación cualitativa y de carácter absoluto". RPS № 115, (1977), pp. 349 y ss.; y DE LA VILLA GIL, Enrique, "Los deberes éticos en el contrato de trabajo". RDTR № 38 (1960) p. 23.

59 Vid. Rodríguez-Piñero y Bravo-Ferrer, "Poder de dirección", cit. nota n. 9, pp. 18 y 19: "El que la buena fe sea, al menos, un valor constitucional permite un replanteamiento de la buena fe como comportamiento honesto y leal exigible al empresario, medio eficaz de limitación y control de los poderes empresariales, e instrumento de información, cooperación, adaptación, transparencia y diálogo entre trabajador y empresario".

${ }^{60}$ Cfr. Conde Marín, La buena fe, cit. nota n. 9, p. 119. Vid. además Gill y Gil, Principio, cit. nota n. 4, pp. 97 y 98, quien expone las tendencias destinadas a vincular la buena fe con las directrices de la Carta Fundamental: "(...) sin elevar la buena fe al rango de principio constitucional, algunos autores la conectan con -o lo deducen de- otros principios constitucionales, como la interdicción de la arbitrariedad, la seguridad jurídica, la solidaridad, el buen funcionamiento de la Administración o la imparcialidad y objetividad de ésta". Y agrega en p. 146: "Podemos formular la hipótesis de que la buena fe es un principio constitucional implícito, por tratarse de un principio inmanente a las relaciones de coordinación (...), un principio de la iustitiaprotectiva en las relaciones de poder (...) y, en suma, un principio constitutivo del Estado de Derecho". Un criterio algo diverso puede consultarse en MORENO García, Antonio, "Buena fe y derechos fundamentales en la jurisprudencia del Tribunal Constitucional", REDC No 38 (1993), pp. 263 y ss., quien estima que la buena fe no constituye un límite inmanente y general a los derechos fundamentales que consagra la Constitución. En igual sentido, ReBollo VARGAS, Rafael, "Los 'otros' límites al ejercicio de los derechos a la libertad de expresión e información: buena fe, honor de la empresa y deber de lealtad al empresario", CDP N 4 (1998), p. 258.
}

${ }^{61}$ Cfr., García Viña, La buena fe, cit. nota n. 7, p. 31: “(..) como concepto indeterminado, exige la oportuna individualización caso por caso, de manera que tampoco son posibles formulaciones generales". 
de una rica casuística que ha obligado a delimitar las figuras propias del ordenamiento jurídico del trabajo, cuestión que se ha vuelto más relevante a partir de procesos desreguladores y del mayor papel de la autonomía contractual ${ }^{62}$.

Desde el punto de vista de su aplicación, la buena fe puede ser analizada en los distintos estadios de desarrollo del vínculo laboral ${ }^{63}$. Ello ocurre en atención que este principio se alza como un estándar que orbita en todo el iter contractual, "desde los tratos preliminares, la celebración del contrato preparatorio y/o definitivo, el cumplimiento del contrato e, incluso, en las relaciones post contractuales" ${ }^{64}$.

\subsection{La buena fe durante los estadios previos al contrato de trabajo}

Como es sabido, la vinculación entre trabajador y empleador puede surgir ya no de un acto instantáneo, sino que, también, de acuerdos preliminares que requieren la ejecución de actos preparatorios. Dichos actos pueden estar conformados por simples tratos preliminares o bien por verdaderos precontratos en el cual existe una promesa formal de dar ocupación a alguien.

\footnotetext{
${ }^{62}$ Vid. Rodríguez-Piñero y Bravo-Ferrer, Poder de dirección, cit. nota n. 9, p. 17: "El proceso desregulador y el mayor papel de la autonomía contractual a la vez que ha fortalecido el poder empresarial ha reforzado posiciones contractuales del trabajador que habían sido oscurecidas por el enorme peso de la tutela legal y colectiva que, en cierta medida, 'expropiaban' o sustituían la tutela contractual. El contrato aparece ahora como un instrumento alegable y oponible al empresario muy particularmente respecto al ejercicio por éste de su poder directivo. Ello explica que haya recobrado actualidad en el contrato de trabajo el papel de la buena fe, de integración de los derechos y deberes del trabajador y empresario y de límite del ejercicio de los poderes empresariales (...)". Cfr. también PLÁ RodríGuez, Américo, "Presencia actual de los principios del Derecho del Trabajo en América Latina", RLCH № 9-10 (1998), pp. 69 y ss.

${ }^{63}$ Cfr., García VIÑA, La buena fe, cit. nota n. 7, p. 228.

${ }^{64}$ Vid., entre otras, Sentencia de la Excma. Corte Suprema de 21 de julio de 2008. № de Ingreso Corte 2594-2007 (aun sin publicar al momento de redactar estas líneas): "La buena fe, en su fase objetiva, está constituido por la conducta que se puede esperar de un hombre correcto. Es un estándar que debe ser apreciado en abstracto, contrariamente a lo que ocurre con la buena fe subjetiva, la cual es ponderada en concreto. Ésta es empleada como sinónimo de probidad, lealtad, confianza, seguridad y honorabilidad, y es por ello que ha tenido su mayor desarrollo en el negocio jurídico, orbitando todo el iter contractual, desde los tratos preliminares, la celebración del contrato preparatorio y/o definitivo, el cumplimiento del contrato e, incluso, en las relaciones post contractuales"; y Sentencia de la Excma. Corte Suprema de 9 de septiembre de 1999, RDJ T. XCVI, sección tercera (1999), p. 183: "Igualmente, posibilitar la revocación unilateral de un despido que ya produjo sus efectos es inaceptable, constituyéndose en una práctica contraria al principio de la buena fe que debe guiar la conducta de las partes durante todo el iter contractual y aun en la fase posterior del mismo". En el plano doctrinal, vid. López SANTA MARía, Los contratos, cit. nota n. 2, p. 292: "La regla o principio de la buena fe objetiva impone a los contratantes el deber de comportarse correcta y lealmente en sus relaciones mutuas, desde el inicio de los tratos preliminares y hasta momentos incluso ulteriores a la terminación del contrato". Y agrega en p. 377: “(...) la buena fe exige, en último término, que el juez interprete aplicando el criterio del 'hombre correcto', preguntándose cómo el prototipo de hombre normal comprendería la convención".
} 
En el primer caso, y a diferencia de lo que ocurre en el precontrato, los tratos preliminares reflejan actos preparatorios destinados a elaborar, discutir y concertar un contrato; pero aquí no hay certeza de que éste vaya a formalizarse, pues en esta etapa de discusión las partes simplemente hacen cálculos y proyecciones que les permita evaluar la cristalización del vínculo. ${ }^{65}$ Durante los tratos preliminares, la buena fe deja en evidencia la ejecución de deberes de comportamiento que se resumen básicamente en tres aspectos: confianza, corrección y cooperación. No es que se pretenda que, en virtud de la buena fe, las partes se entiendan obligadas a consumar un contrato que se encuentra en un mero estadio previo. Simplemente, lo que se pide es sujetar el actuar propio a actitudes de confianza, corrección y cooperación.

En el precontrato, por su parte, la buena fe obliga a la ejecución de ciertos deberes de conducta compatibles con la misma. En este último caso no estamos en presencia de una etapa de formación contractual (cuestión que sí es predicable de los tratos preliminares), sino que, por el contrario, existe un acuerdo definido que comenzará a producir efectos a partir de un determinado plazo o bien para el evento de que ocurra una condición previamente fijada. En ese contexto, durante el precontrato se deberán observar las reglas generales predicables de la buena fe contractual.

Como se ha dicho, durante los estadios previos la buena fe le impone a los contratantes un conjunto de deberes de confianza, corrección y cooperación. Entre ellos, los más destacados son los siguientes: (i) los deberes de información y transparencia, según los cuales los contratantes están obligados a entregar información completa y veraz, que contribuya a la formación de un consentimiento más claro y reflexivo ${ }^{66}$. Lo anterior supone, desde luego, un deber de dar y recibir información relevante para la toma de decisiones. Más allá de la casuística en la entrega de antecedentes, no cabe duda que las notas comunes que definen una información relevante son aquellas que pueden ser consideradas como pertinentes, veraces, claras y exactas. Por ello, habrá que concluir que se atenta en contra de la buena fe cuando se entrega información de modo oscuro o ininteligible, o evitando que la contraparte pueda acceder de forma prístina a la misma ${ }^{67}$. Por el contrario,

\footnotetext{
${ }^{65}$ Vid. por todos García VIÑA, La buena fe, cit. nota n. 7, p. 231: "No existe un derecho de buena fe en las negociaciones entre personas para que éstos lleguen a un acuerdo (...), pero sí puede existir algo que los obligue al deber de buena fe en las negociaciones (...)".

${ }^{66}$ Cfr. Gill y GIL, "La buena fe", cit. nota n. 50, p. 22.

${ }^{67}$ Vid. Conde Marín, La buena fe, cit. nota n. 9, p. 174, quien considera que atenta contra el deber de buena fe "quien realiza afirmaciones falsas, engañosas por no ser completas, quien actúa sibilinamente o causando impresiones equivocadas induciendo al error en el receptor de la información. O quien practica la reserva mental, la ambigüedad calculada, la reticencia fraudulenta o incluso simplemente
} 
el trabajador no está obligado a entregar información frente a preguntas discriminatorias ${ }^{68}$, sobre aspectos que no guarden relación con el empleo ofrecido, ${ }^{69} \mathrm{o}$ atentatorias de derechos fundamentales ${ }^{70}$; (ii) los deberes de confidencialidad y secreto. Siempre que las negociaciones sean consideradas reservadas, nuevas y concretas, ambas partes se encuentran sujetas a una conducta de esta naturaleza ${ }^{71}$. El quebrantamiento de la confidencialidad y del secreto, sobre todo en relación con materias relevantes, importaría un evidente menoscabo para su eventual contratante, y (iii) los deberes de rectitud y respeto al interés de la contraparte, cuestión que implica encuadrar su actuación sin perjudicar al otro. Por ejemplo, no sería admisible que, en la etapa de formación del contrato, el empleador aprovechara su posición de privilegio contractual para imponer al trabajador cláusulas vejatorias o abusivas.

En los tratos preliminares, y aun cuando no existe una decisión definitiva para celebrar el contrato, resulta evidente que las partes que negocian se encuentran obligadas por un deber básico de actuar lealmente. Entre ellos existe

el silencio". Lo anterior no obsta, según la autora citada, a que se le exija al otro contratante "un mínimo de diligencia en el transcurso de las negociaciones" (p. 176). Más aún, en países como Alemania, el artículo 123 del Código Civil establece que el empresario tiene derecho a impugnar el contrato cuando ha sido engañado en las respuestas frente a preguntas a las cuales está autorizado a formular. Un caso singular relata Gı y GIL, Principio, cit. nota n. 4, p. 212, ocurrido en el Derecho belga: "Un empresario ocultó a la trabajadora a la que iba a confiar la gerencia de una tienda, y a la que había ofrecido un contrato de duración indefinida, que el arrendamiento del negocio expiraba a los siete meses de comenzar la relación laboral. Como esta información podría haber sido determinante para la trabajadora, el empresario incurrió en una culpa in contrahendo. El Tribunal declaró nulo el contrato y condenó al empresario al pago de una indemnización".

${ }^{68}$ Cfr. GoÑ Sein, José Luis, El respeto a la esfera privada del trabajador, Civitas, $1^{\text {a }}$ edición, Madrid 1988, pp. 41 y ss.

${ }^{69}$ Cfr., Däubler, Wolfang, Derecho del Trabajo. Traducción de María Paz Acero Serna y Pío Acero López. Centro de Publicaciones Ministerio de Trabajo y Seguridad Social, Madrid 1994, pp. 526 y ss.). En el Derecho francés, por su parte, el artículo L 121-6 II del Código laboral establece que el trabajador debe responder de buena fe a las preguntas que se le hagan.

${ }^{70}$ Vid. Montora Melgar, La buena fe, cit. nota n. 15, p. 71: "En particular, (el trabajador) se encuentra legitimado para no contestar aquellas preguntas que revelen un ánimo discriminador o atentatorio contra derechos fundamentales; un ejemplo de ello lo ofrece el Código del Trabajo francés cuando reconoce el derecho de la mujer a no revelar su embarazo". En igual sentido, Däubler, Derecho, cit. nota n. 69, p. 531: "Por eso el BAG concedió al candidato, en su constante jurisprudencia, el derecho a dar una contestación incorrecta (...): quien no tenga antecedentes penales pertinentes puede ser considerado 'sin antecedentes penales' y quien enferme de gripe en repetidas ocasiones puede, sin embargo, contestar el cuestionario diciendo que está 'sano'. También se puede ocultar el embarazo (...)".

${ }^{71}$ Vid. por todos López SANTA MARía, Los contratos, cit. nota n. 2, p. 297: "La buena fe impone reserva respecto a las informaciones adquiridas en torno al estado de los negocios del otro, a sus proyectos comerciales y a los demás aspectos de su actividad cuya divulgación pudiere causarle perjuicio". 
una vinculación jurídica especial que les impone una actuación honrada ${ }^{72}$. Eso exige un esfuerzo sincero no tanto en la cristalización misma del contrato, sino que en la coherencia de las actuaciones preparatorias ${ }^{73}$. Y ello es así, toda vez que en los tratos preliminares se persigue como principal objetivo el suministrar antecedentes que permitan comprobar si a los hipotéticos contratantes les interesa o no llevar a término un acuerdo efectivo y concluyente. ${ }^{74}$ Si en ese escenario, alguien actúa de mala fe o sin justa causa, entonces el infractor está obligado a resarcir los daños injustamente ocasionados ${ }^{75}$. En esta perspectiva, habrá dos tipos de conductas especialmente reprochables desde el punto de la buena fe: la salida intempestiva de las negociaciones, quebrando de esta manera la confianza depositada por la otra parte; y la ejecución de actos que supongan daños materiales a la contraparte. Si el actuar del infractor carece de razonabilidad y termina provocando una ruptura injustificada, entonces, se obliga a reparar los perjuicios causados. Aquí no se trata de obligar a la otra parte a formalizar un contrato sobre el cual ni siquiera existe voluntad de perfeccionarlo; simplemente, lo que se busca es resarcir a la víctima del perjuicio de los daños indebidamente provocados.

\subsection{Las exigencias de buena fe durante el desarrollo del contrato}

El principio de la buena fe informa todas las relaciones obligatorias, de modo tal que las normas y las declaraciones de voluntades deben medirse conforme a él. En el caso del trabajador (en su calidad de deudor de trabajo), la buena fe le impone el deber de cumplir la obligación debida "no sólo a

\footnotetext{
72 Cfr. Larenz, Derecho, cit. nota n. 19, T. I. p. 107.

${ }^{73}$ Vid. en este sentido GıL y GIL, Principio, cit. nota n. 4, p. 256: “(...) revela una actitud contraria a la buena fe iniciar y mantener las negociaciones sin intención alguna de llegar a un acuerdo. (...) atenta contra la buena fe ofrecer a un candidato puestos que no existen o unas perspectivas de promoción ilusorias"; y Escudero, Frigola y Corbella, El principio, cit. nota n. 3, p. 68: "En general, hay una actitud contraria a la buena fe, iniciar y mantener negociaciones, cuando se ha tomado ya la decisión de no contratar".

74 Como señala Conde Marín, La buena fe, cit. nota n. 9, pp. 158 y 159: "Se puede transgredir la buena fe de diversas maneras; por ejemplo: cuando con la finalidad de obtener un provecho se finge en ignorar lo que se sabe, cuando se oculta la verdad a quien no pudo conocerla, cuando se va contra la resultancia de los actos propios, cuando se realiza un acto equívoco para beneficiarse intencionalmente de su dudosa significación o cuando se crea una apariencia jurídica para contradecirla después, en perjuicio de quien puso su confianza en ella". En igual sentido, VILlAÇá AzeVEdo, "Buena fe", cit. nota n. 28, p. 141: "Así incumple ese deber de informar aquel que, en las tratativas y negociaciones, esconde, por medio de disimulación, la realidad sobre un hecho relevante y determinante para la realización del negocio; da inicio y continuidad a las tratativas, sabiendo que no va a realizar el negocio, creando falsas expectativas a la otra parte; omite, por negligencia o ignorancia culposa, la existencia de una causa de invalidez o ineficacia del negocio".

75 Vid. por todos IruRETA URIARTE, Pedro, "Estadios previos al contrato de trabajo: tratos preliminares y precontrato". Estudios Laborales No 2 (2008), p. 53.
} 
la letra, sino también al espíritu de la relación obligatoria correspondiente (...) y en la forma que el acreedor puede razonablemente esperar de él". Con respecto al empleador(quien en el ámbito laboral se comporta como acreedor de trabajo), la buena fe impone "el mandato de ejercitar el derecho que le corresponde, actuando según la confianza depositada por la otra parte"

La buena fe tiene, dentro de sus finalidades, el modalizar el ejercicio de los derechos subjetivos, nivelando los intereses de cada parte, y juridificando los poderes de los contratantes. Ello es especialmente atendible durante la ejecución misma del contrato, ya que ambas partes están obligadas a realizar el programa negocial de forma coherente, leal y correcta ${ }^{77}$. Nada de ello impide concluir que la buena fe se encuentra íntimamente asociada a la existencia del contrato y no exclusivamente a la ejecución misma; es decir, la buena fe también resulta aplicable a aquellos períodos de vinculación contractual que, aun cuando las partes tengan suspendidas sus obligaciones primordiales, igual deben entenderse sujetas a parámetros propios de la buena $\mathrm{fe}^{78}$. Lo anterior resulta aún más relevante si se considera que en el ámbito de las relaciones de trabajo uno de los contratantes, el empleador, goza de un cierto status jurídico que explica parte importante de sus poderes de dirección y de disciplina. De esta manera, la buena fe actúa como límite y control intrínseco de las atribuciones y poderes que se derivan del ejercicio de un derecho ${ }^{79}$.

En este contexto, la buena se alza en el ámbito laboral como un verdadero telón de fondo que permite completar el acuerdo de las partes y circunscribir el ejercicio de los derechos subjetivos ${ }^{80}$. Y esta lógica deriva, entre otras, de

\footnotetext{
${ }^{76}$ Vid. LaRenz, Derecho, cit. nota n. 19, T. I, p. 148.

77 Vid. Montoya Melgar, La buena fe, cit. nota n. 15, pp. 39 y 43. Vid. también García ViÑa, La buena fe, cit. nota n. 7, p. 81, quien siguiendo la tendencia del Derecho anglosajón señala: “(...) el problema de la buena fe en el cumplimiento del contrato surge cuando el contrato da a una parte un grado de discrecionalidad en la concreción, y esta discrecionalidad es usada por esta parte para recuperar una oportunidad que ya había perdido en la formación de dicho contrato". Sobre la necesidad de que el contrato de trabajo se ejecute de buena fe, vid. además, y entre otras muchas, Sentencia de la lltma. Corte de Apelaciones de Santiago de 25 de junio de 2002, GJ No 264 (2002), p. 228; Sentencia de la Excma. Corte Suprema de 26 de septiembre de 2001, GJ N 255 (2001), p. 167; y Sentencia de la lltma. Corte de Apelaciones de Santiago de 07 de marzo de 2001, GJ № 249 (2001), p. 201.

${ }^{78}$ Cfr., LLuIS NAVAS, "El principio", cit. nota n. 8, p. 631. Lo que ocurre es que existen variados deberes de abstención (cuyo fundamento no se encuentra en la efectiva prestación de servicios), aplicables en períodos de interrupción, suspensión o no prestación de labores, o en casos de incapacidad temporal, que deben ser respetados por las partes, ya que de otra forma se verificaría una infracción a la buena fe.

79 Cfr., Rodríguez-Piñero y Bravo-Ferrer, "Poder de dirección”, cit. nota n. 9, p. 19.

${ }^{80}$ En palabras de Montora Melgar, La buena fe, cit. nota n. 15, p. 90: "la buena fe es (...) la atmósfera en la que debe desenvolverse el tráfico jurídico en su integridad y, por tanto, el cauce natural por el que ha de discurrir el ejercicio de los derechos, incluidos, cómo no, los fundamentales". En el plano jurisprudencial, cfr. Sentencia de la Excma. Corte Suprema de 17 de marzo de 2003, RDJT. C, sección tercera (2003), p. 24; y Sentencia de la Iltma. Corte de Apelaciones de Santiago de 19 de enero de 2001,
} 
la norma del artículo 1546 del Código Civil, el cual establece -al estilo de una cláusula general- que los contratos deben ejecutarse de buena fe: "(...) y por consiguiente obligan no sólo a lo que en ellos se expresa, sino a todas las cosas que emanan precisamente de la naturaleza de la obligación, o que por ley o la costumbre pertenecen a ella"81. La fuerza expansiva de este tipo de normas obliga a concluir que ellas son aplicables al negocio jurídico en general $^{82}$. Lo que ocurre es que en el Derecho de Obligaciones, todas las relaciones de obligación se encuentran afectas al principio de buena $\mathrm{fe}^{83}$.

RDJT. XCVIII, sección segunda (2001), p. 11; Sentencia de la Iltma. Corte de Apelaciones de Santiago de 05 de junio de 1985, RDJT. LXXXII, sección tercera (1985), p. 123; y Sentencia de la Excma. Corte Suprema de 31 de julio 1990, RDJ, T. LXXXVII, sección tercera (1990), p. 91.

81 La misma lógica puede observarse en cierta jurisprudencia nacional. Por ejemplo, en Sentencia de la Iltma. Corte de Apelaciones de Santiago de 26 de mayo de 1986, RDJ T. LXXXIII, sección tercera (1986), p. 99: "El empleador bancario debe cumplir de buena fe las diversas obligaciones que derivan de su contrato de trabajo no sólo de acuerdo a lo expresamente estipulado sino que también conforme a todo lo que por la ley o la costumbre le pertenezca, $y$, en especial, todo lo que emana de la naturaleza de la obligación laboral propia de la actividad bancaria". En igual sentido, Sentencia de la Iltma. Corte de Apelaciones Pedro Aguirre Cerda de 14 de julio de 1988, GJ No 97 (1988), p. 97: "CUARTO: Que los contratos, cualesquiera que sea su naturaleza, deben ejecutarse de buena fe, y por consiguiente obligan no sólo a lo que en ellos se expresa, sino a todas las cosas que emanan precisamente de la naturaleza de la obligación, o que por la ley o la costumbre pertenecen a ella. QUINTO: Que el contrato de trabajo de conductor de bus, aunque nada se diga, Ileva consigo no sólo la obligación propiamente tal de guiar el vehículo, sino que, además, de hacerlo en la debida forma, sin infringir las normas del tránsito, en general, y sin tener u ocasionar colisiones con otros vehículos, etc.". La norma del artículo 1546 CC es similar a otras consagradas en los ordenamientos civiles. En Alemania, por ejemplo, el artículo 157 del BGB establece que los "contratos deben interpretarse como lo exige la buena fe determinada según costumbre". Por su parte, el artículo 242 del mismo cuerpo legal indica que el "deudor está obligado a efectuar la prestación como lo exige la buena fe determinada según costumbre". En Italia, destaca el artículo 1375 del Código Civil (bastante similar al artículo 1546 del Código chileno, toda vez que establece que el contrato debe ser cumplido según la buena fe), el artículo 1366 del mismo cuerpo legal, sobre interpretación, y el artículo 1337 relativo a los tratos preliminares y a la formación del contrato. Más aún, el artículo 1175 de dicho Código señala que el acreedor y el deudor deben actuar en conformidad a las exigencias de la correteas. En el Código Civil francés debe destacarse el artículo 1134, según el cual las convenciones legalmente pactadas deben ser ejecutadas de buena fe. El Código Civil español, por su parte, contiene la siguiente orientación preceptiva en su artículo 1258: "Los contratos se perfeccionan por el mero consentimiento y desde entonces obligan, no sólo al cumplimiento de lo expresamente pactado, sino también a todas las consecuencias que, según su naturaleza, sean conformes a la buena fe, al uso y a la ley". La mayor parte de estas formulaciones configuran a la buena fe como un principio general del Derecho que se formula a través de una cláusula general.

${ }^{82}$ Cfr. De los Mozos, El principio, cit. nota n. 2, p. 124. Vid. también WIEACKER, El principio, cit. nota n. 6, pp. 87 y ss.

83 Vid. por todos EnneCCerus, Ludwig, KIPP, Theodor, y WolfF, Martín, Tratado de Derecho Civil, T. II, Vol. I. Bosch, Barcelona 1947, p. 19: "(...) la doctrina dominante y, en particular, la jurisprudencia han deducido como principio supremo y absoluto que domina todo el derecho de obligaciones, el de que todas las relaciones de obligación, en todos los aspectos y en todo su contenido, están sujetas al imperio de la buena fe, pero teniendo presente que el contenido de la deuda, cuando se trata de 
Estas exigencias son inderogables por las partes y resultan predicables tanto del empleador como del trabajador ${ }^{84}$. Dicha reciprocidad en el cumplimiento de la buena fe permite sostener que ambos contratantes se encuentran obligados no sólo a abstenerse de conductas deshonestas (v. gr., no engañar o no defraudar); sino que también se encuentran obligados a realizar actos positivos que permitan el normal desenvolvimiento del acuerdo contractual ${ }^{85}$. Y entre dichos actos también habrá que incorporar a las declaraciones unilaterales que realicen las partes ${ }^{86}$.

Al configurarse a la buena fe como un límite intrínseco de las atribuciones de cada parte, huelga concluir que todos los poderes y atribuciones de los contratantes se ven modalizados por el cumplimiento de los deberes propios de la buena fe (aun cuando el ordenamiento jurídico no haya normativizado expresamente estas exigencias). Y el carácter recíproco de ésta permite disociar los deberes de lealtad de una pura exigencia de fidelidad, más aún si esta última se concebía como un deber del trabajador y un exclusivo derecho del empleador ${ }^{87}$.

Esa exigencia de buena fe no admite grados ${ }^{88}$, no es que en un caso se puedan exigir mayores deberes de buena fe y en otros no, pues en definitiva ambas partes se encuentran obligadas por un deber genérico, recíproco, de adecuar sus conductas a los postulados de la buena fe. Por ello se tiende a concluir que la buena fe no puede ser objeto de graduación cuantitativa ya que, en rigor, "se actúa o no se actúa de buena fe". Lo anterior implica aceptar que no hay mayores deberes de corrección y lealtad predicables de un contratante en desmedro del otro; ambos se entienden igualmente

obligaciones derivadas de negocio jurídico, se determina en primer término por la voluntad de los interesados, mientras en las obligaciones legales esta voluntad es indiferente".

${ }^{84}$ Vid. LARENZ, Derecho, cit. nota n. 19, T. I, p. 145: "El principio (de la buena fe) es irrenunciable, ya que representa el precepto fundamental de la juridicidad". Cfr. también Difguez Cuervo, La fidelidad, cit. nota n. 16, p. 14; LaSARTE, "Sobre la integración", cit. nota n. 2, p. 73; y Ferreira Rubio, La buena fe, cit. nota n. 5, p. 206. A mayor abundamiento, cfr., también, en el plano jurisprudencial, Sentencia de la lltma. Corte de Apelaciones de Concepción de 13 de octubre de 2000, RDJT. XCVII, sección tercera (2000), p. 180: " $9^{\circ}$ (...) el deber de 'lealtad' o de 'fidelidad', que constituye un deber recíproco, en cuanto resulta exigible tanto al trabajador como al empleador, cuya forma de cumplimiento es diferente según la parte obligada de que se trate".

${ }^{85}$ Cfr. Conde Marín, La buena fe, cit. nota n. 9, pp. 242 y 243. Vid. también Escudero, Frigola y Corbella, El principio, cit. nota n. 3, p. 38.

${ }^{86}$ Cfr. Ferreira Rubio, La buena fe, cit. nota n. 5, p. 199.

${ }^{87}$ Cfr. De la Villa Gill, "Los deberes éticos”, cit. nota n. 58, p. 25. Vid. también Dieguez Cuervo, Gonzalo, Lecciones de Derecho del Trabajo. Civitas, 2ª edición, Madrid 1988, p. 211.

${ }^{88}$ Vid., por todas, Sentencia de la Excma. Corte Suprema de 14 de diciembre de 1981, RFM № 277, diciembre, 1981, p. 590; y Sentencia de la Excma. Corte Suprema de 11 de junio de 1970, RDJ, T. LXVII, sección tercera, 1970, p. 51. 
obligados desde sus respectivas posiciones de acreedor laboral y deudor de trabajo ${ }^{89}$.

La circunstancia de que los deberes de buena fe no tengan que estar debidamente positivizados, no ha impedido que el legislador haya incorporado dentro del catálogo normativo una serie de figuras que reflejan plenamente la aplicación de este principio en el campo de las relaciones de trabajo. ${ }^{90}$ Ello demuestra la relevancia que la ley le otorga a esas figuras, y potencia a este principio en el sentido de asegurar que los derechos y las obligaciones deben ejercitarse de acuerdo a la buena fe. Este grado de recepción normativa no es sistemático ni menos obedece a un criterio uniforme, al menos en el orden laboral. Lisa y llanamente, el legislador ha recogido este principio para ciertos casos, adecuando la conducta del empleador o del trabajador a los criterios generales de la buena fe.

En el caso chileno, no existen referencias directas al principio, salvo en materia procesal laboral. No obstante, el artículo 1546 CC ha consagrado expresamente estas directrices en una norma que ciertamente termina aplicándose en materia labora ${ }^{91}$. Este artículo permite que la buena fe se incorpore en el plano de la norma dispositiva, integrando y corrigiendo la voluntad de los contratantes. De esta forma, la ejecución de los contratos debe llevarse a cabo sin apego a la letra rigurosa de ellos ni a un derecho estricto. Como ha señalado la jurisprudencia, no deben las partes "asilarse en la literalidad inflexible para dar menos ni para exigir más, arbitrariamente, al influjo de un interés propio y mezquino; antes bien ha de dejarse expresar al contrato ampliamente su contenido. Tampoco debe dejarse de atender a factores extraliterales que pudieran fundarse en la naturaleza del pacto, en la costumbre o en la ley". ${ }^{92}$

No obstante lo anterior, y tal como se ha advertido, el ordenamiento laboral chileno consagra algunas figuras legales que típicamente responden a las exigencias de la buena fe. Ejemplo de ello son los deberes de información, de seguridad e higiene, o la obligación de dar ocupación efectiva, entre otras varias alternativas. Dicha regulación legal es una muestra de la generalización que ha alcanzado la buena fe más allá de los Códigos civi-

\footnotetext{
89 Vid., Montoya Melgar, La buena fe, cit. nota n. 15, p. 50.

90 Cfr., Plá Rodríguez, Américo, Los principios del Derecho del Trabajo. Depalma, 2a edición, Buenos Aires 1978, p. 306.

91 Un análisis de la aplicación jurisprudencial de este precepto puede consultarse en CORRAL TALCIANI, Hernán, "La aplicación jurisprudencial de la buena fe objetiva en el ordenamiento civil chileno". Tratado de la Buena Fe en el Derecho. Director Marcos M. Córdoba. La Ley, Buenos Aires 2004, 205 y ss.

${ }_{92}$ Cfr. Sentencia de la Iltma. Corte de Apelaciones Presidente Aguirre Cerda de 4 de marzo de 1988, RDJT. LXXXV, sección segunda (1988), p. 9.
} 
les y una reafirmación del valor que el legislador le otorga a la seguridad del tráfico jurídico. Esta positivización, además, ha permitido concretizar supuestos específicos del deber de buena fe. ${ }^{93}$

\subsubsection{La buena fe en el caso del trabajador}

El trabajador, en su calidad de deudor de trabajo, se obliga a observar una conducta conforme a los deberes de la buena fe ${ }^{94}$. Ello lo obliga a conducirse con probidad, honestidad y celo, de forma tal que no defraude los intereses de la contraparte ${ }^{95}$. Dada la especial vinculación del trabajador en la relación laboral, en épocas relevantes de la evolución del Derecho del Trabajo se puso mayor atención en la buena fe exigible a aquel en su calidad de deudor de trabajo; pero en caso alguno ello ha podido servir de pretexto para ignorar el carácter recíproco de este deber.

La exigencia de que el trabajador se comporte conforme a la buena fe, implica que éste debe abstenerse de ejecutar conductas eventualmente reprochables ("aun cuando no le hubiere sido especialmente prohibido") ${ }^{96}$. En esta perspectiva, y si bien nuestra legislación no contempla un catálogo de deberes del trabajador, en razón de la buena fe, resulta perfectamente posible extraer algunos prototipos de supuestos que dejan en evidencia estos deberes. Lo anterior no supone que la buena fe sólo puede ser invocada en aquellos casos en que la ley expresamente ha regulado su concurrencia; pero desde luego el hecho de que se encuentre positivizada para determinados casos permite descubrir aquellos puntos especialmente relevantes para el ordenamiento jurídico-laboral.

a. El deber de diligencia del trabajador

Por la celebración del contrato de trabajo, el trabajador asume un deber inicial: cumplir con sus obligaciones de forma diligente. Es decir, no basta con ejecutar el contrato pura y simplemente; además, en la obligación contractual

93 Cfr. Gil y Gil, Principio, cit. nota n. 4, p. 141.

${ }_{94}$ Vid. por todos Montora Melgar, Alfredo, Derecho del Trabajo.Tecnos, $29^{a}$ edición, Madrid 2008, p. 323: “(...) el trabajador, junto al cumplimiento fiel de su prestación laboral, es deudor de específicas obligaciones de buena fe".

${ }_{95}$ Cfr., CONDE MARín, La buena fe, cit. nota n. 9, p. 381. En el plano jurisprudencial vid. Sentencia de la Excma. Corte Suprema de 5 de marzo de 2009. № de Ingreso Corte: 7789-08 (aun sin publicar al momento de redactar estas líneas): “(...) el actor incumplió con los deberes de cuidado, corrección social, fidelidad y lealtad que le imponía su contrato de trabajo (...); consecuentemente, tal infracción debe calificársele de grave, ya que con su actuar, se produjo indudablemente el quiebre de la relación laboral existente entre las partes, pues independientemente del monto posible del daño, la conducta del trabajador resultó contraria a dicha ética".

${ }^{96}$ Vid. Sentencia de la Iltma. Corte de Apelaciones de Santiago de 26 de mayo de 1986, RDJ T. LXXXIII, sección tercera (1986), p. 99. 
subyace el deber de comportarse de forma diligente. ${ }^{97}$ Dicha diligencia refleja un conjunto de deberes representativos de una conducta activa y determinada del trabajador que permita satisfacer el interés de su contraparte y ejecutar la tarea concreta que le impone el contrato. Como es sabido, la diligencia admite una doble configuración en objetiva y subjetiva: la primera pone el acento en el resultado, en la obtención del rendimiento, y la subjetiva se caracteriza por los cuidados y cautelas ${ }^{98}$ Pero, salvo en el caso de aquellos trabajadores que se encuentran afectados por alguna discapacidad, ${ }^{99}$ lo cierto es que la diligencia objetiva es la que prima en materia laboral.

Diligencia y buena fe no son conceptos intercambiables, sino que representan ámbitos distintos de actuación. ${ }^{100}$ Si se quiere, entre ambos conceptos existe una relación de género a especie; más aún, el trabajo diligente presupone la existencia de un marco mayor fundado en la buena fe. La diligencia se asocia indefectiblemente al cumplimiento idóneo de la prestación debida. El deber de trabajar y el deber de ser diligente es una moneda de dos caras, de tal forma que si el trabajador lleva a cabo su función sin la diligencia necesaria, entonces se incurre en un tipo de incumplimiento contractual sancionado por el legislador. De allí que la diligencia se asocie con la aptitud, con la pericia o con la idoneidad del trabajador. ${ }^{101}$

\footnotetext{
97 Vid. Conde Marín, La buena fe, cit. nota n. 9, p. 255: “(El) concepto de buena fe absorbe dentro de sus más vastas y elásticas fronteras a aquel de la diligencia"; y Montora Melgar, Derecho, cit. nota n. 94, p. 320: "No existe, pues, un deber de trabajar, por un lado, y un deber de ser diligente, por otro (...). En resumen, la diligencia es un requisito esencial de esta prestación (....)". En el plano jurisprudencial, vid., Sentencia de la Excma. Corte Suprema de 31 de marzo de 2004, GJ № 286 (2004), p. 293: “(...) estos sentenciadores dan por establecida la negligencia del trabajador en la conducción y cuidado de un vehículo de la empresa, cuyo uso le estaba permitido para el desempeño de las funciones propias de su cargo (...); obligación cuyo incumplimiento configura la causal del $\mathrm{N}^{\circ} 7$ del artículo 160 del Código del Trabajo, por cuanto al no estar probada la eximente alegada por el actor -frenos en mal estado- la obligación de conducir con prudencia formaba parte de aquellas propias de su función de vendedor con salidas a terreno"; y Sentencia de la Iltma. Corte de Apelaciones de Concepción de 06 de septiembre de 2002, GJ № 267 (2007), p. 191: "Los deberes de conducta, Ilamados también en doctrina 'obligaciones de solidaridad y colaboración', constituyen comportamientos ínsitos del contrato de trabajo, que tienen una connotación ética, y entre los cuales se cuenta el 'deber de diligencia y rendimiento' impuesto al trabajador, que se concreta en la obligación de dar en su trabajo el rendimiento propio o normal del buen trabajador".

98 Vid. Montora Melgar, Derecho, cit. nota n. 94, p. 320.

99 Cfr. artículo 161 bis CT.

${ }^{100}$ Cfr. García ViÑa, La buena fe, cit. nota n. 7, p. 111. Sobre las diferencias entre buena fe y diligencia, vid. del mismo autor pp. 113 y ss. Vid. también Ferreira Rubio, La buena fe, cit. nota n. 5, p. 226. Con todo, tanto la diligencia como la buena fe se expresan como modos de comportamiento que en último término se conectan tal como ocurre, por ejemplo, en la debida observancia de los deberes de seguridad e higiene.

101 Vid. Montoya Melgar, Derecho, cit. nota n. 94, p. 320: “(...) la diligencia consta de un elemento interno y subjetivo (...) y un elemento objetivo, de un resultado (la obtención del rendimiento). Igual-
} 
Por cierto, el cumplimiento de este deber no supone cualquier diligencia. Se trata de aquella que sea acorde con la naturaleza de la obligación y que se encuentre en correspondencia con las circunstancias de las personas, del tiempo y del lugar. Como ha dicho la jurisprudencia, la diligencia laboral exige un rendimiento propio o normal del buen trabajador. ${ }^{102}$ De esta manera, la diligencia le impone al prestador de los servicios, a lo menos, tres deberes subyacentes: (i) En primer lugar, existe una obligación de diligencia conservativa, en cuya virtud el trabajador que no está prestando servicios efectivos debe abstenerse de acciones que perjudiquen la adecuada ejecución del trabajo. No sería diligente un trabajador que perturba y evita que el resto de los trabajadores desarrolle normalmente sus obligaciones; (ii) en segundo lugar, la diligencia exige realizar el trabajo con la pericia necesaria a objeto de que la obligación sea ejecutada correctamente. La pericia se vincula estrechamente con la idoneidad, de forma tal que lo exigido es aquello que regularmente se espera del trabajador, y (iii) por último, la diligencia impone que la prestación sea llevada a cabo "con la intensidad que exija el cumplimiento de la obligación en atención a las circunstancias del tiempo y del lugar"103.

b. Los deberes de cooperación

La buena fe también implica la obligación del trabajador de someterse a niveles esperables de cooperación. Esta actitud está en la base de las obligaciones contractuales y deja en evidencia un compromiso leal con el programa negocial ${ }^{104}$.De esta forma, se espera una conducta que no obstruya ni dificulte el cumplimiento de las obligaciones contractuales. Desde luego, no se trata de una cooperación de carácter asociativo, ni menos relacionadas con una sujeción personal propia de las teorías corporativas, sino que se vincula más bien a exigencias de respeto al legítimo interés de la contraparte más aún si en la especie existen intereses contrapuestos ${ }^{105}$. Desde esta perspectiva, el trabajador se entiende que colabora cuando ejecuta la actividad de acuerdo a

mente posee la diligencia un aspecto cualitativo (según el cual el trabajador diligente deberá alcanzar un nivel correcto en la calidad de su prestación) y otro cuantitativo (según el cual deberá obtener un nivel correcto en la cantidad de trabajo realizado)".

102 Cfr. Sentencia de la Iltma. Corte de Apelaciones de Concepción de 06 de septiembre de 2002, GJ No 267 (2007), p. 191.

${ }^{103}$ Vid. García Viña, La buena fe, cit. nota n. 7, pp. 118 y 119.

104 Cfr. Montoya Melgar, La buena fe, cit. nota n. 15, p. 69. Vid. también Plá Rodríguez, Los principios, cit. nota n. 90, p. 307. Un complemento de estas ideas, en el ordenamiento nacional, puede observarse en el inciso segundo del artículo 153 CT, el cual obliga a que en el Reglamento Interno se consagren normas que garanticen "un ambiente laboral digno y de mutuo respeto entre los trabajadores".

105 Cfr. Gil. y Gil, Principio, cit. nota n. 4, p. 194. Vid., además, del mismo autor, "La buena fe",cit., p. 6: "En el contrato de trabajo, se da lo que podríamos denominar una 'cooperación antagónica' o una cooperación conflictiva". 
las expectativas que se ha creado el empleador en razón de sus habilidades y experiencia profesional. También se da cumplimiento a estos deberes cuando la colaboración permite el debido cumplimiento del contrato ${ }^{106}$.

Los deberes de cooperación se expresan en tareas y obligaciones concretas. Y en ese ámbito, existen a lo menos tres deberes que deben ser resaltados: el deber de aviso, el deber de secreto y el deber de cuidado. (i) El deber de aviso, trasunta un deber general de información y comunicación por parte del trabajador. Estas exigencias, por cierto, siempre se entienden vinculadas al puesto de trabajo del dependiente y a la naturaleza de las obligaciones por él asumidas ${ }^{107}$; (ii) El deber de secreto, obliga a guardar la debida confidencialidad y discreción sobre determinados asuntos o informaciones de las cuales tome conocimiento el trabajador en razón de su cargo ${ }^{108}$. Se trata, por cierto, de antecedentes relevantes, sobre los cuales existe un interés fundado en que no sean divulgados. Y en esta perspectiva, debieran ser consideradas como informaciones relevantes aquellas de carácter técnico, científico o de recursos. Igual conclusión habría que sacar con respecto a todas aquellas materias que se encuentran vinculadas a la intimidad, el honor o la privacidad del empleador. Por el contrario, la revelación de irregularidades que suponen un funcionamiento anormal de la empresa y que, en el caso de hacerse públicas, benefician al interés social, no debieran quedar cubiertas por este deber. Tampoco pueden estarlo los actos ilícitos cometidos por el empleador ${ }^{109}$, y (iii) Los deberes de cuidado. Con ello se hace referencia al cumplimiento de obligaciones vinculadas con la asistencia, guarda y conservación de las personas y de las $\cos ^{1} \mathrm{~s}^{110}$. Dentro de las expresiones más elocuentes de este deber se encuentran las prohibiciones de soborno y sabotaje. También se suele incluir dentro de esta categoría a las prohibiciones de competencia desleal a que se refiere el artículo $160 \mathrm{~N}^{\circ} 2 \mathrm{CT}$.

106 Cfr. Dieguez Cuervo, La fidelidad, cit. nota n. 16, p. 39. Vid. también Rebollo Vargas, "Los 'otros' límites", cit. nota n. 60, p. 255.

107 Vid. en esta línea Sentencia de la Iltma. Corte de Apelaciones de Santiago de 26 de mayo de 1986, $R D J$ T. LXXXIII, sección tercera (1986), p. 99.

${ }_{108}$ Cfr., en el ámbito penal, la norma del artículo 284 CP que sanciona a aquel que "fraudulentamente hubiere comunicado secretos de la fábrica en que ha estado o está empleado". La misma lógica existe en el inciso segundo del artículo 247 CP, que sanciona a los que "ejerciendo alguna de las profesiones que requieren título, revelen los secretos que por razón de ella se les hubieren confiado". En el plano laboral, vid. también los artículos 290, letra e), y 388, letra d), del Código del Trabajo, que sancionan a los miembros de un directorio sindical, o de una comisión negociadora, que divulgan a terceros ajenos a éste los documentos o la información que se ha recibido del empleador y que tenga el carácter de confidencial o reservados.

109 Vid. Rebollo Vargas, “Los 'otros' límites", cit. nota n. 60, p. 255.

110 Vid. a modo de ejemplo la definición que consagra el artículo 152 ter A CT, para el caso de tripulación de cabina: "Son aquellos trabajadores que (...) participan de las labores de servicio y atención de pasajeros, así como del cuidado y seguridad de las personas o cosas que se transporten en la aeronave". 


\section{c. Los deberes de confianza}

Una mención aparte merecen las exigencias derivadas del principio de confianza. Como se sabe, la buena fe es un concepto estrechamente vinculado a la confianza mutua ${ }^{111}$, aun cuando la sobrepasa en su extensión ${ }^{112}$. A ello habría que agregar que, en el ámbito laboral, todos los trabajos Ilevan envuelto un deber básico de probidad y corrección por parte del trabajador, que se funda precisamente en la confianza de su contraparte. Por ello, e independientemente de la tarea asumida, y del cargo que se ostente, el trabajador no puede eludir estos deberes básicos. De allí que no pueda competir deslealmente con su empleador, que no pueda aceptar sobornos ni recibir gratificaciones o revelar los secretos relativos a la empresa. Tampoco puede abusar de la confianza en él depositada.

Lo anterior no impide sostener que el cargo o función configura los límites obligacionales del trabajador, así como de los derechos subjetivos que subyacen en el poder de dirección del empleador ${ }^{113}$. Dicho cargo o función permite conocer a qué se encuentra específicamente obligado el trabajador y qué puede exigirle su empleador. Por tanto, conductas que pueden resultar completamente irrelevantes en un determinado dependiente, adquieren relevancia en otros en atención a la buena fe exigida y a la confianza en él depositada ${ }^{114}$.

Con todo, dentro del catálogo de alternativas que presenta la realidad laboral, existe un colectivo de trabajadores que se vincula con el empleador precisamente en razón de la confianza en él depositada. No es la misma confianza a que se ha hecho referencia en el párrafo anterior; por el contrario, se trata de una especial posición al interior de la organización empresarial que deja en evidencia que ciertos trabajadores se encuentran muy próximos o cercanos al empleador, como si se tratase de una especie de alter ego de éste. La concurrencia de esa confianza acentúa el carácter personalísimo del cargo, cuestión que obliga a que el trabajador ejecute conductas posi-

\footnotetext{
111 Cfr. Grodeau, "Lealtad", cit. nota n. 5, p. 302.

112 Cfr. Gil y GIL, Principio, cit. nota n. 4, p. 181.

113 Cfr., GarCía VIÑA, La buena fe, cit. nota n. 7, p. 282: “(...) existe una relación directa entre el puesto de trabajo y la manera en que la buena fe ha de estar presente (...)". Vid. también Alonso OleA, Manuel, El despido. Instituto de Estudios Políticos, Madrid 1958, p. 147. A mayor abundamiento, en el plano jurisprudencial, cfr. Sentencia de la Iltma. Corte de Apelaciones de Santiago de 26 de mayo de 1986, RDJT. LXXXIII, sección tercera (1986), p. 99.

114 Un caso singular menciona Montoya Melgar, La buena fe, cit. nota n. 15, p. 58, a partir de la jurisprudencia comparada. Un tribunal "declaró procedente el despido de un trabajador por haber sustraído... una bombilla. Lo que a primera vista parece un caso de extrema severidad judicial revela enseguida su justificación: quien sustrajo la bombilla era precisamente el encargado de evitar sustracciones similares, y además la bombilla era la que iluminaba el despacho del jefe".
} 
tivas que traspasan el mero deber de la prestación de trabajo ${ }^{115}$. Ese es el caso, por ejemplo, del alto directivo, del trabajador de casa particular, o de toda persona que ha ingresado a la organización empresarial para dirigir y gestionar la empresa. ${ }^{116}$ También se suele incluir dentro de esta categoría a los trabajadores de empresas ideológicas y a los trabajadores que manejan recursos o valores del empleador ${ }^{117}$.

En todos estos casos, el trabajador de exclusiva confianza se ve obligado a un deber mayor de buena fe que sea acorde con la posición que se ocupa al interior de la organización creada por el empleador. De allí que si este trabajador vulnera la confianza en él depositada, o abusa de la misma, entonces se entiende que se ha incurrido en una modalidad cualificada de infracción a la buena fe ${ }^{118}$.

\subsubsection{La buena fe en el caso del empleador}

En el caso del empleador, la buena fe se alza, en primer lugar, como un mecanismo de juridificación de sus poderes y de limitación y control de sus atribuciones. Las facultades del empleador no deben ser entendidas como derechos omnímodos; por el contrario, dichas atribuciones sólo se entienden dentro de un ejercicio racional y funcional, en que la buena fe termina circunscribiendo el verdadero alcance de las mismas. En definitiva, la buena fe permite pregonar la interdicción de discrecionalidad abusiva o

115 Cfr. Sierra Herrero, Alfredo, Administradores de sociedades mercantiles y altos directivos laborales. Aranzadi, $1^{\text {a }}$ edición, Pamplona, 2008, p. 115.

116 El concepto de exclusiva confianza es una cuestión de apreciación que debe estar fundamentada en la naturaleza misma de la función desempeñada. En general, estos cargos deben ser referidos a ciertos puestos claves dentro de la estructura de la organización, que corresponde desempeñarlos a trabajadores únicos o de excepción, los que toman a su cuidado la marcha de los negocios o de un establecimiento en particular, con facultades para administrarlos, dirigirlos en general e incluso obligar al empleador frente a terceros.

117 Vid. García VIÑa, La buena fe, cit. nota n. 7, pp. 285 y ss., quien agrupa a este tipo de trabajadores en siete categorías: (i) Aquellos que ejecutan labores revestidos de una cierta confianza; (ii) Aquellos trabajadores que desempeñan cargos cuya nota $n$. característica es el hecho de suponer una intervención decisiva en el conjunto de las actividades de la empresa en la que prestan sus servicios; (iii) "La buena fe se exige con mayor rigor según la responsabilidad del cargo desempeñado por el trabajador"; (iv) Aquellos que ejercen cargos de relevante categoría; (v) Puestos de trabajo que tienen asignados una contraprestación económica de cuantía importante; (vi) Puestos de trabajo en los que el trabajador puede llevar a cabo una prestación laboral que pueda ser un ejemplo y modelo de conducta para todas las personas relacionadas con él, y (vii) Puestos de trabajo que presentan una cierta autonomía en cuanto a su desarrollo.

118 Cfr. Conde Marín, La buena fe, cit. nota n. 9, p. 384. 
discriminatoria, todo lo cual consigue estructurar la exacta dimensión de los poderes del empleador. ${ }^{119}$

Por cierto, no es que la buena fe amplíe o restrinja las atribuciones del empleador; lo que hace este principio es configurar adecuadamente los poderes empresariales dentro de los márgenes contractuales, constituyéndose en un instrumento de corrección y también de garantía para el trabajador. ${ }^{120}$ En el Derecho del Trabajo, y a diferencia de otros órdenes normativos, las atribuciones del empleador, en tanto acreedor, se encuentran fuertemente reguladas ya sea por la ley o por la negociación colectiva. Más aún, la función integrativa de la buena fe, destinada a llenar lagunas, debiera ser de una magnitud menor si se le compara con otro tipo de contratos ${ }^{121}$.

La juridificación de los poderes del empleador obliga a conectar sus atribuciones con el denominado principio de razonabilidad, según el cual ningún derecho puede ejercerse de forma irrazonable ${ }^{122}$. Dicho principio exige que el acreedor laboral ajuste su conducta a los predicados del orden legal, y también a las exigencias de la buena fe. Y es ahí donde entra a tallar la razonabilidad: no basta un mero cumplimiento de la ley, sino que, además, debe ajustarse el comportamiento y el ejercicio del poder de dirección a las directrices de la buena fe.

a. La exacta configuración de los poderes de dirección y de disciplina

Como es ampliamente sabido, de la condición de acreedor surgen para el empleador determinados poderes de dirección, organización y disciplina. El contenido de estos poderes está conformado por una pluralidad de derechos subjetivos de ordenación, especificación y corrección de la concreta prestación de servicios que realiza el trabajador. Desde luego, el ejercicio de estos poderes debe llevarse a cabo de acuerdo a los parámetros de la buena $\mathrm{fe}^{123}$ : y dichos parámetros están configurados por la razonabilidad, la proporciona-

\footnotetext{
119 Vid. Conde Marín, La buena fe, cit. nota n. 9, p. 318.

120 Cfr. Escudero, Frigola y Corbella, El principio, cit. nota n. 3, p. 45.

121 Cfr. García Viña, Jordi, "La regulación actual de la buena fe en la figura del empresario", AS N 22 (2000), p. 3.

122 Sobre la vinculación entre buena fe y razonabilidad, vid. GIL y GIL, Principio, cit. nota n. 4, p. 286 y ss.

123 Vid. Rodríguez-Piñero y Bravo-Ferrer, "Poder de dirección", cit. nota n. 9, p. 18 En igual sentido, vid. Carrizosa Prieto, Esther, "El principio de proporcionalidad en el derecho del trabajo", REDT $N^{0} 123,(2004)$, p. 493. En el ámbito legal, vid. el inciso final del artículo 154 CT, el cual exige que las medidas de control que implemente el empleador se efectúen por "medios idóneos y concordantes con la naturaleza de la relación laboral". Y agrega: "(...) en todo caso, su aplicación deberá ser general, garantizándose la impersonalidad de la medida, para respetar la dignidad del trabajador". En el plano comparado, vid. el artículo 120-2 del Código del Trabajo francés: "nadie puede aportar a los derechos de las personas y a las libertades individuales y colectivas, restricciones que no se puedan justificar por la naturaleza de la tarea a realizar, y que no sean proporcionales al objetivo buscado".
} 
lidad, la justificación, la imparcialidad y la paridad de tratamiento, de forma tal que dichos atributos no sean utilizados como excusa de arbitrariedad o de manifiesta iniquidad. Esto obliga a prohibir el uso abusivo de los poderes y a motivar las decisiones del empleador dentro de los márgenes que imponen la razonabilidad y la funcionalidad.

Un ejemplo directo de estas referencias se encuentra en el inciso primero del artículo $5^{\circ}$ del Código del Trabajo, en cuya virtud el "ejercicio de las facultades que la ley le reconoce al empleador, tiene como límite el respeto a las garantías constitucionales de los trabajadores, en especial cuando pudieran afectar la intimidad, la vida privada o la honra de éstos". Dentro de este esquema, el empleador no puede asilarse en el ejercicio de sus poderes para restringir el goce de los derechos fundamentales del trabajador ${ }^{124}$.

Consecuente con lo anterior, el legislador le prohíbe al empleador difundir antecedentes sensibles del trabajador, o datos privados del mismo, y de los cuales haya tomado conocimiento con ocasión de la relación laboral ${ }^{125}$. También se le

124 Aun cuando se trata de una norma de carácter general, el legislador ha dispuesto redacciones similares con respecto al contrato de deportistas profesionales y en relación con los deberes de la empresa usuaria en el contrato de trabajadores transitorios. En el primer caso, y en atención a las particularidades de la actividad regulada, el Código dispone que los deportistas profesionales y trabajadores que desempeñen actividades conexas tendrán derecho a manifestar libremente sus opiniones sobre temas relacionados con su profesión (art. 151 bis L). Se trata de una norma singular: en principio, no se entiende bien por qué motivo la ley explicita el derecho a la libertad de expresión sólo en este caso en particular y no en otros. La explicación para ello parece fundarse en la especialidad de la actividad y en la sobre- exposición que por regla general tienen este tipo de trabajadores. Además, normas de esta naturaleza tendrían "una finalidad pedagógica social recordatoria" (vid. RoQUETA Bus, Remedios, El trabajo de los deportistas profesionales. Tirant lo Blanch, Valencia 1996, p. 164). Con todo, ello no podría llevar a sostener que el mismo derecho no es predicable de los demás trabajadores regidos por un contrato laboral común. De hecho, el artículo 291 CT, letra b), sanciona -por ser contrario a la libertad sindical- a los que "por cualquier medio entorpezcan o impidan la libertad de opinión de los miembros de un sindicato". Por cierto, el reconocimiento de esta libertad no podría llevar a sostener que se trata de un derecho absoluto, pues el trabajador también debe ejercer sus derechos en forma razonable (cfr., GIL y GlL, "La buena fe", cit. nota n. 50, p. 40). En lo que dice relación con los trabajadores transitorios, el Código ha dispuesto una norma de igual respeto a los derechos fundamentales, pero ahora referida no al empleador formal, sino que a la empresa usuaria: "El ejercicio de las facultades que la ley le reconoce a la usuaria tiene como límite el respeto a las garantías constitucionales de los trabajadores, en especial cuando pudiera afectar la intimidad, la vida privada o la honra de éstos" (art. 183-Y). Una norma de esta naturaleza era del todo necesaria, pues la referencia consignada en el artículo $5^{\circ}$ del Código del Trabajo sólo era predicable del empleador formal. Como la empresa usuaria no es el empleador ante la ley (a pesar de que ejerce el poder de dirección y organización con respecto al trabajador transitorio, tal como lo dispone el artículo 183-X CT), resultaba lógico que el legislador ampliara la exigencia de respeto a los derechos fundamentales para este empresario.

125 Cfr. artículo 154 bis CT. Vid. también los artículos $9^{\circ}$ y 10 de la Ley № 19.628, sobre protección de la vida privada o protección de datos de datos de carácter personal (DO 28 de agosto de 1999). En el plano doctrinal, vid. GoÑ SEIN, José Luis, "Límites constitucionales a los reconocimientos médicos obligatorios establecidos como medida de prevención de riesgos laborales", RDS № 5 (1999), p. 55. Vid. también, CARDONA RUBERT, María Belén, "Tutela de la intimidad informática en el contrato de trabajo", RDS No 6 (1999), pp. 23 y ss.; y Fernández Villazón, Luis Antonio, "Tratamiento automatizado 
prohíbe traspasar los límites propios de la intimidad del trabajador ${ }^{126}$. Incluso, en el Derecho comparado, se ha prohibido la realización de exámenes médicos generalizados y sin justificación, los dictámenes grafológicos, las entrevistas estresantes o el análisis de genomas por estimarse que ellas afectan la dignidad del trabajador o bien vulneran sus derechos fundamentales ${ }^{127}$.

de datos personales en los procesos de selección de trabajadores". Relaciones Laborales T. I (1994), pp. 510 y ss.

126 Vid. en esta línea Sentencia de la Excma. Corte Suprema de 05 de enero de 2006, GJ № 307 (2007), p. 289: "Dentro del recinto laboral, constituido por el ámbito de actividades propio de los empleados, los trabajadores tienen derecho a la privacidad o intimidad, manifestándose ello en el deseo de que, como en el caso de autos, se mantenga en la esfera laboral y sindical las actividades realizadas por ellos, sin que en él se permita la intromisión de terceros. Lo anterior puede ser compatibilizado con la existencia de un sistema de vigilancia y protección en el recinto laboral, pero éste no debe estar desviado de los fines que justificaron su instalación. De lo dicho resulta que la utilización de cámaras de video por la empresa recurrida, en la forma realizada, a más de ilegal, vulnera la garantía invocada por los actores (...)". En el plano doctrinal (vid. GarCía VIÑA, "La regulación actual", cit. nota n. 121, p. 11), la instalación de circuitos cerrados de televisión, o de cámaras de video, ha sido considerado justificado siempre y cuando cumpla con las exigencias de proporcionalidad. Entre ellas, destacan las siguientes: "a) (Si) existen razonables sospechas de la comisión de graves irregularidades por parte de alguno de los trabajadores; b) (Si) es idónea, para la finalidad pretendida por la empresa, que es verificar si realmente existen dichas irregularidades y en tal caso adoptar las medidas correspondientes, y c) (Si) es necesaria y equilibrada".

127 Vid. entre otros Fernández Domínguez, Juan José, Pruebas genéticas en el Derecho del Trabajo. Civitas, $1^{\text {a }}$ edición, Madrid 1999, pp. 107 y ss.; SAGardor BenGochea, Juan Antonio, Los derechos fundamentales y el contrato de trabajo. Civitas, $1^{\text {a }}$ edición, Madrid 2005, pp. 49 y ss.; VALDÉs DAL-Ré, Fernando, "Poderes del empresario y derechos de la persona del trabajador". Autoridad y Democracia en la empresa. Trotta, Madrid 1992, pp. 27 y ss.; y GoÑI SEIN, El respeto, cit. nota n. 68, pp. 209 y ss. En Alemania, los dictámenes grafológicos sólo se permiten si cuentan con la autorización del interesado. Las entrevistas estresantes han sido consideradas, por lo general, como contrarias a la dignidad humana, pues lo único que buscan es colocar al trabajador en una situación de estrés y conocer de manera amplia su personalidad. En lo que respecta al análisis de genomas, el ordenamiento jurídico alemán estima "que no se puede permitir en principio semejante invasión de la esfera privada humana, porque en ella se somete al interesado a un reconocimiento mucho más intenso que el conseguido en otras pruebas psicológicas y entrevistas estresantes, sin dejar de escudriñar nada de su esfera íntima". Por otra parte, la normativa alemana sólo acepta las pruebas psicológicas si se cumplen los siguientes requisitos: (i) Que el candidato de su conformidad; (ii) Que se le hubiere indicado previamente al candidato la forma en que se realizará la prueba y cuáles son los datos que se desean obtener; (iii) Que se trate de conocer los datos referentes al puesto de trabajo; (iv) Que los datos requeridos no se puedan obtener por otro procedimiento; y (v) Que la prueba psicológica la realice un licenciado en una Escuela Superior (sobre el particular vid. DÄUBleR, Derecho, cit. nota n. 69, pp. 532 y ss.). En materia de exámenes médicos, la necesidad de su realización se encuentra íntimamente vinculada a la identificación de patologías o condiciones de salud incompatibles con el trabajo desempeñado. "Pero este tipo de reconocimiento obligatorio, que, a mi juicio, sólo sería posible ante la exigencia de 'indicios racionales' (...) de pérdida de aptitud que sugieran una reevaluación del sujeto, se inscribe no tanto en una finalidad de prevención, sino en la constatación de las capacidades del trabajador desde el punto de vista de los requisitos de idoneidad física-psíquica para desempeñar un puesto de trabajo" (vid. GoÑ Sein, "Límites constitucionales", cit. nota n. 125, p. 70). En cualquier caso, los exámenes médicos deben respetar la intimidad, la dignidad y la confidencialidad del trabajador; incluso, éste siempre tiene derecho a conocer el resultado de los mismos (cfr., GARCía VIÑA, "La regulación actual", 
"Vigencia del principio de la buena fe en el derecho del trabajo chileno"

\section{b. El deber de protección}

Un segundo deber básico del empleador, vinculado a la buena fe, se refiere a la protección del trabajador. Por cierto, no se trata de un deber de corte paternalista, asociado a conductas extralaborales del trabajador; simplemente, este deber hace referencia a obligaciones legales y contractuales básicas del empleador en orden a cumplir las normas de seguridad y salud ${ }^{128}$. Esta obligación de cuidado resulta ser de mayor entidad que aquella que comúnmente se exige en los contratos bilaterales, pues sobre el empleador no sólo pesa el deber de tomar todas las medidas de seguridad necesarias para proteger la vida y la salud de sus trabajadores, sino que también debe hacerlo de manera eficaz ${ }^{129}$.

cit. nota n. 121, p. 12). Con todo, es preciso aclarar que los derechos fundamentales no constituyen cláusulas ilimitadas y absolutas, ya que en distintas situaciones encuentran un límite en el derecho ajeno o en el ejercicio de otras garantías constitucionales. Por ello, no resultaría aceptable pretender justificar un incumplimiento contractual irracional en base a la mera invocación de los derechos. Asimismo, y a diferencia de lo que ocurre en el sector público, el empleador debe respetar los derechos fundamentales del trabajador, pero no se encuentra obligado a promocionar o fomentar estos derechos. Sobre el particular, vid. GARCíA VIÑA, "La regulación actual", cit. nota n. 121, p. 14: "(...) no existe una función promocional o prestacional de las libertades constitucionales a cargo del empresario. Éste sólo estará obligado a respetar el ejercicio de los derechos fundamentales de los trabajadores (...), pero no a potenciar, fomentar o facilitar su actuación (....)". A mayor abundamiento, vid. GIL y GIL, Principio, cit. nota n. 4, p. 233: "El principio de neutralidad del empresario (...) sirve para excluir que éste tenga el deber de facilitar el ejercicio de los derechos fundamentales del trabajador".

${ }^{128}$ Vid. en esta línea, Sentencia de la Excma. Corte Suprema de 29 de abril de 2004, RDJT. Cl, sección tercera (2004), p. 57: "El deber de seguridad contemplado en el artículo 184 del Código del Trabajo constituye una de las varias manifestaciones del deber general de protección que se impone al empleador, cuyo origen algunos autores lo sitúan en la contrapartida al deber de fidelidad y lealtad atribuidos al trabajador, otros en la situación de la comunidad jurídico-personal que caracteriza a la vinculación laboral, otros en el principio pro-operario, etcétera"; y Sentencia de la Excma. Corte Suprema de 08 de agosto de 2000, GJ № 237 (2000), p. 159: “(..) es el artículo 184 el que establece el deber general de protección de la vida y salud de los trabajadores, impuesto por el legislador a los empleadores, en términos tales que el empleador es un deudor de seguridad a sus trabajadores y tal obligación de otorgar seguridad en el trabajo, bajo todos sus aspectos, es una de las manifestaciones de aquel deber general de protección ya citado, cuyo cabal e íntegro cumplimiento es de una trascendencia superior a la de una simple obligación a que se somete una de las partes de una convención y, evidentemente, constituye un principio que se encuentra incorporado a todo contrato (...)". En el plano doctrinal, vid. Thayer Arteaga, William, y Novoa Fuenzalida, Patricio, Manual de Derecho del Trabajo, T. II. Editorial Jurídica de Chile, $3^{a}$ edición, Santiago 1998, pp. 377 y 378.

129 Cfr. Sentencia de la Iltma. Corte de Apelaciones de Santiago de 22 de abril de 2003, GJ № 274 (2003), p. 281. En igual sentido, cfr. Sentencia de la Iltma. Corte de Apelaciones de Santiago de 30 de septiembre de 2003, GJ № 279 (2003), p. 270. En el plano doctrinario, vid. SupIOT, Alain, Derecho del Trabajo. Traducción de Patricia Rubini-Blanco. Heliasta, Buenos Aires 2008, p. 114: "El empleador, con respecto a sus asalariados, tiene una obligación de seguridad de resultado, y el simple hecho de no tomar las medidas necesarias para preservarlos de los peligros de los que tiene o tendría que tener conciencia constituye una falta inexcusable de su parte (...)". 
Este deber presenta una doble naturaleza pública y privada ${ }^{130}$ : desde la perspectiva meramente contractual, la buena fe se alza como el fundamento del deber de protección del empleador; pero ello no evita la existencia de una frondosa normativa, de muy distinto orden, en cuya virtud el Estado asegura el cumplimiento de ciertos parámetros básicos.

Un buen ejemplo de estas exigencias se encuentra en el artículo 184 del Código del Trabajo, según el cual el empleador estará obligado a tomar todas las medidas necesarias para proteger eficazmente la vida y salud de los trabajadores, manteniendo las condiciones adecuadas de higiene y seguridad en las faenas, como también los implementos necesarios para prevenir accidentes y enfermedades profesionales. "Deberá asimismo prestar o garantizar los elementos necesarios para que los trabajadores en caso de accidente o emergencia puedan acceder a una oportuna y adecuada atención médica, hospitalaria y farmacéutica"131. De forma complementaria, el artículo 187 del Código prohíbe la admisión del trabajador en faenas superiores a sus fuerzas o que comprometan su seguridad; y el artículo 189 CT regula las prestaciones de servicios en trabajos considerados subterráneos.

En el fondo, todo este juego normativo deja en evidencia que el empleador se constituye en un deudor de seguridad, el cual debe evitar -en el medio laboralriesgos para la vida, la integridad física-síquica y la salud de los trabajadores, cuestiones todas que se derivan de condiciones materiales, personales y organizativas. ${ }^{132} \mathrm{El}$ fundamento de estas exigencias arranca de la propia Constitución (art. $19 \mathrm{~N}^{\circ} 18$ CPR) y de un entramado normativo, bastante heterogéneo, que obligan a que el empleador cumpla con una serie de exigencias legales que se incorporan automáticamente en el contenido del contrato de trabajo.

En este orden de ideas, un comportamiento leal y correcto del empleador le obliga no sólo a cumplir con aquellas cuestiones mínimas de cuidado. También debe extremar todas las medidas necesarias para evitar que el trabajador puede verse expuesto a dificultades o accidentes que afecten su integridad tanto física como sicológica. Y ello es así, pues resulta que el empleador tiene la titularidad del lugar y de las condiciones en que se prestan los servicios; por tanto, esa

\footnotetext{
${ }^{130}$ Cfr. GIL y GIL, Principio, cit. nota n. 4, p. 204. Vid. además GoÑı SEIN, "Límites constitucionales", cit. nota n. 125, p. 66.

131 Cfr. también el artículo 154 № 9 CT, en relación con las disposiciones que debe contener el Reglamento Interno en materia de prevención, higiene y seguridad.

132 Vid. González Ortega, Santiago, "Seguridad e higiene en el trabajo". Enciclopedia Jurídica Básica, T. IV. Dirección de Alfredo Montoya Melgar. Civitas, $1^{\text {a }}$ edición, Madrid 1995, p. 6100. En el plano jurisprudencial, vid. sentencia de la Corte de Apelaciones de Concepción de 12 de diciembre de 2007. Ingreso Corte № 423-2007 (aun sin publicar al momento de redactar estas líneas); y Sentencia de la Iltma. Corte de Apelaciones de Santiago de 02 de junio de 2004, GJ № 288 (2004), p. 296.
} 
titularidad lo obliga a responder con eficiencia frente a los requerimientos de seguridad que requiere el trabajador para ejecutar sus actividades.

En esta misma línea, otro ejemplo destacable de aceptación legal de la buena fe se produce en los deberes de prevención del acoso sexual. El propio artículo $2{ }^{\circ} \mathrm{CT}$ considera contrario a la dignidad del trabajador "el acoso sexual, entendiéndose por tal el que una persona realice en forma indebida, por cualquier medio, requerimientos de carácter sexual, no consentidos por quien los recibe y que amenacen o perjudiquen su situación laboral o sus oportunidades de empleo". Por ello, el legislador le ha exigido al empleador que una vez recibida la denuncia de acoso, adopte las medidas de resguardo necesarias respecto de los involucrados "considerando la gravedad de los hechos imputados y las posibilidades derivadas de las condiciones de trabajo"133.

c. El deber de dar ocupación efectiva

Una obligación básica que recae sobre el empleador es la de dar ocupación efectiva al trabajador. Se trata de una obligación eminentemente contractual, y por tanto vinculada a la buena $\mathrm{fe}^{134}$. Para estos efectos, el empleador debe facilitar la ejecución de las labores, suministrar los medios idóneos para el cumplimiento de este fin, y llevar a cabo todas aquellas tareas consideradas indispensables para el normal desenvolvimiento del vínculo contractual.

Si bien se trata de una obligación predicable de cualquier contrato de trabajo, el Código chileno ha omitido referencias expresas en lo que respecta al contrato común de trabajo. Por el contrario, en materia de contratos especiales, nuestro legislador ha establecido algunas reglas específicas que es necesario destacar. Así ocurre, por ejemplo, en el caso de los trabajadores de artes y espectáculos, en que el artículo 145-J dispone que no se podrá, "de manera arbitraria, excluir al trabajador de artes y espectáculos de los correspondientes ensayos ni de las demás actividades preparatorias para el ejercicio de su actividad artística". Un criterio similar se consagra en el artículo 152 bis K, según el cual los deportistas profesionales y los trabajadores que desempeñen actividades conexas no podrán ser objeto de sanciones que supongan "la exclusión de los entrenamientos con el plantel profesional".

Desde luego, el deber de ocupación efectiva tiene algunas excepciones legítimas fundadas en motivos ocasionales o irresistibles, o bien por causas legales o no imputables al empleador. En ese cuadro estarían los supuestos de huelga o conflicto colectivo, los impedimentos fundados en la fuerza mayor o los casos de inasistencia injustificada a las labores.

Con todo, la obligación de dar ocupación efectiva se alza como un deber esencial del contrato por parte del empleador e inherente a un proceder funda-

${ }^{133}$ Cfr. artículo 211-B CT.

${ }^{134}$ Cfr., Dieguez, La fidelidad, cit. nota n. 16, p. 20. 
do en la buena fe. Por ello, de ninguna manera sus atribuciones organizativas podrían justificar la falta de ocupación por parte del trabajador ${ }^{135}$. Más aún, cualquier acto del empleador tendiente a excluir al trabajador de sus funciones, supondría un incumplimiento grave de las obligaciones por parte del acreedor de trabajo. En razón de lo anterior, la principal obligación que asume el empleador es otorgarle a su contraparte el trabajo contractualmente convenido, y cualquier modificación sólo puede limitarse a los supuestos de iusvariandi $i^{136}$.

El deber de dar ocupación efectiva trae aparejado algunas obligaciones complementarias. Por una parte, el empleador no sólo se encuentra obligado a pagar la remuneración por el trabajo convenido, sino que, además, debe ejecutar una conducta que no impida ni obstaculice el cumplimiento regular por parte del trabajador. De igual forma, el empleador debe abstenerse de realizar cualquier conducta que suponga negar la ocupación efectiva con fines vejatorios ${ }^{137}$. Por último, y fundado en las exigencias de la buena fe, el empleador se encuentra obligado a certificar los servicios realizados por el trabajador cuando éste así lo solicite ${ }^{138}$.

d. El deber de informar al trabajador

Los deberes de información se encuentran íntimamente vinculados a la buena fe. En rigor, estos deberes son predicables de toda relación laboral y, en este sentido, no cabe duda que el vínculo contractual entre trabajador y empleador debe estar presidido por la transparencia y por la apertura a toda aquella información necesaria para el normal desenvolvimiento de los derechos y obligaciones de ambas partes. De allí que, toda información relevante, debe ser puesta en conocimiento del trabajador, ya sea para ejercer un derecho o reclamación, o para cumplir una obligación ${ }^{139}$.

En puridad de términos, los deberes de información han estado incorporados desde antiguo en el ordenamiento laboral. La diferencia es que, durante gran parte de su desarrollo, las exigencias que el empleador tenía en esta materia se circunscribían preferentemente al ámbito colectivo. No obstante, la legislación, así como los Convenios internacionales, han venido reglamentando el cumplimiento de algunos deberes de información en el campo del Derecho individual

\footnotetext{
135 Cfr., Conde, La buena fe, cit. nota n. 9, p. 304.

136 Cfr. artículo $10 \mathrm{~N}^{\circ} 5$ y 12 CT. En el plano doctrinal, cfr. HueCK y NiPPERDEY, Compendio, cit. nota n. 58, p. 113; y Escudero; Frigola; Corbella, El principio, cit. nota n. 3, pp. 49 y 50.

137 Cfr. Montoya Melgar, Derecho, cit. nota n. 94, p. 400.

138 Cfr. Gil y GIL, Principio, cit. nota n. 4, p. 226; y García, "La regulación actual", cit. nota n. 121, p. 17.

139 Un ejemplo de ello puede consultarse en el artículo 156 CT, el cual obliga a que el Reglamento Interno sea puesto en conocimiento de los trabajadores.
} 
en materias tales como remuneraciones ${ }^{140}$, jornada laboral ${ }^{141}$ y extinción del contrato de trabajo ${ }^{142}$.

El deber de informar es una obligación de ejecución continuada, que en determinadas materias adquiere una relevancia sustantiva. Así ocurre, por ejemplo, en el ámbito de la seguridad y salud en el trabajo, en cuya virtud el empleador se encuentra obligado a suministrar información relevante sobre los riesgos del puesto de trabajo y sobre los medios de protección necesarios para su adecuada ejecución. Prueba de ello se encuentra, entre otros, en el inciso primero del artículo 184 CT que obliga a que el empleador tome las medidas necesarias para proteger la vida y salud de los trabajadores, "informando de los posibles riesgos y manteniendo las condiciones adecuadas de higiene y seguridad $(\ldots)^{\prime \prime 143}$.

Con todo, el deber de informar exige circunscribir algunos requisitos básicos a objeto de establecer con claridad qué tipo de información es la que debe entregar el empleador. En principio, éste no está obligado a entregar cualquier información sino sólo aquella que se estime pertinente para el cumplimiento de los fines contractuales. Un buen cumplimiento del deber de información, permitirá que el trabajador optimice la ejecución de sus obligaciones contractuales.

Las peticiones de información que formule el trabajador deben ser directas, formales, y contener los elementos esenciales para el cumplimiento del contrato ${ }^{144}$. Pero, al mismo tiempo, e incluso en aquellos casos en que el empleador no está obligado por ley a entregar determinada información, de todas formas debe responder las consultas y peticiones de sus dependientes acompañando "los antecedentes que la empresa estime necesarios para la mejor información de los trabajadores"145. Ello es una manifestación palmaria de las exigencias derivadas de la buena fe, y que obliga a que el empleador actúe con transparencia y precisión en sus respuestas.

\footnotetext{
${ }^{140}$ Cfr. artículo 54, inciso tercero, CT.

141 Cfr. artículo 12, inciso segundo, CT.

${ }^{142}$ Cfr. artículo 162 CT. Vid. además Gil y Gil, Principio, cit. nota n. 4, pp. 206 y 207.

${ }^{143}$ En igual sentido, vid. el inciso segundo del artículo $92 \mathrm{CT}$, referido al contrato de trabajo de trabajadores agrícolas: "El empleador deberá, en todo caso, prestar al trabajador que realice labores en que tenga contacto con pesticidas, plaguicidas o productos fitosanitarios tóxicos, (...) información suficiente sobre su correcto uso y manipulación, eliminación de residuos y envases vacíos, riesgos derivados de su exposición y acerca de los síntomas que pudiere presentar y que revelen su inadecuada utilización. $(\ldots)^{\prime \prime}$. La misma norma se reproduce en el artículo 95, inciso tercero, ahora referido a los trabajadores agrícolas de temporada.

144 Cfr. Conde Marín, La buena fe, cit. nota n. 9, p. 302.

145 Cfr. artículo 155 CT.
} 
Por otra parte, y aun cuando no dice relación con un derecho específico de los trabajadores, cabe destacar los deberes de información que se producen en los supuestos de subcontratación de obra o servicios. Como es sabido, el artículo 183-C del Código del Trabajo obliga a que el contratista le informe a la empresa principal, cuando así lo solicite, "el monto y estado de cumplimiento de las obligaciones laborales y previsionales que a éstos correspondan respecto a sus trabajadores, como asimismo de igual tipo de obligaciones que tengan los subcontratistas con sus trabajadores". Este deber de información se satisface con certificados emitidos por la respectiva Inspección del Trabajo, "o bien por medios idóneos que garanticen la veracidad de dicho monto y estado de cumplimiento". La infracción de este deber por parte del contratista no es inocuo para él: si no entrega completa y oportuna información, la empresa principal adquiere el derecho de retener de las obligaciones que tenga a favor del contratista el monto del cual éste es responsable en razón de obligaciones laborales y previsionales de sus trabajadores. Asimismo, el requerimiento de información por parte de la empresa principal supondrá modificar su responsabilidad: de solidaria a subsidiaria ${ }^{146}$.

\section{e. Los deberes de formación}

El ordenamiento laboral parte de la base de que el contrato de trabajo le permite al trabajador el cumplimiento de ciertos derechos de formación. Esos derechos se vinculan con la dignidad que pregona tanto la Constitución (art. $1^{\circ} \mathrm{CPR}$ ) como el propio Código del Trabajo (art. $2^{\circ} \mathrm{CT}$ ), permitiendo el libre desarrollo de la personalidad. En lo que respecta al desenvolvimiento de la relación laboral, se parte de la base que la buena fe le impone al empleador obligaciones generales de formación que afecten directamente al trabajador. Así, por ejemplo, se le impone al empleador el deber de adaptación del traba-

\footnotetext{
${ }^{146}$ En otro orden, pero vinculado a los deberes de información, resalta la norma del artículo 152 bis J, en relación con el contrato de deportistas profesionales. En este caso, el legislador obliga a que el empleador le informe a un ente privado (que no es un ente público ni un contratista, y que tampoco ostenta funciones para estatales) -la entidad superior de la respectiva disciplina- sobre "el monto y estado de cumplimiento de las obligaciones laborales y previsionales" de los trabajadores que prestan servicios a las entidades deportivas que participan en las competencias que organiza. El precepto en comento está inserto dentro de las hipótesis de cesión temporal de deportistas profesionales, razón por la cual el legislador razona de la misma manera en que lo ha hecho en los casos de cesión de trabajadores transitorios. Como la entidad superior de la respectiva disciplina es la encargada de organizar la competencia, entonces existen derechos y obligaciones pecuniarias que se vinculan con ella. En esa lógica, si el empleador no acreditare el oportuno cumplimiento de las obligaciones laborales y de seguridad social, la ley faculta a que la entidad superior retenga las sumas adeudadas. Más aún, el inciso final del artículo 152 bis J, del Código del Trabajo, aplica la misma norma que regula los derechos de información en materia de subcontratación: "El monto y estado de cumplimiento de las obligaciones laborales y previsionales (...) será acreditado en la forma establecida en el inciso segundo del artículo $183 \mathrm{C}(\ldots)^{\prime \prime}$.
} 
jador al puesto de trabajo a objeto de que el prestador ejecute la obligación de forma idónea ${ }^{147}$.

Adicionalmente, sobre el empleador pesan dos grupos de acciones propias de la formación. En primer término, debe asumir un rol de no interferencia en las actividades formativas que lleve a cabo el trabajador, sin poner trabas ni limitaciones injustificadas en el ejercicio de los derechos de formación y capacitación. Por otra parte, el propio legislador ha regulado figuras especiales de formación a las cuales el empleador se encuentra obligado. Así ocurre, por ejemplo, en el contrato de aprendizaje en que el motivo principal de la contratación es precisamente la formación ${ }^{148}$.

\section{La buena fe en materia de extinción del contrato de trabajo}

Las reglas generales de la buena fe se encuentran ampliamente recogidas en las normas reguladoras de la extinción contractual. Es precisamente en dicha materia, donde el principio despliega gran parte de sus postulados y exigencias. De allí que tengamos que sostener que las causas disciplinarias de terminación, así como las normas generales que regulan el comportamiento del sujeto en el ámbito que rodea la extinción, permiten concluir que la buena fe se encuentra ampliamente recogida.

Lo normal, en materia de buena fe, es que no existan conductas preestablecidas o estereotipos, salvo por cierto de aquellas conductas penalmente prohibidas. Desde esta perspectiva, resultaría imposible establecer un catálogo de conductas contrarias a la buena fe, ya que ello significaría dejar fuera un universo de alternativas que probablemente no han sido tipificadas.

En la etapa extintiva, no obstante, la regla de la buena fe-considerada como un modelo de conducta- puede ser contrariada dolosa o culposamente ${ }^{149}$. Ello ha obligado a que el Código del Trabajo opte por consagrar un listado de infracciones disciplinarias, muchas de ellas de contextura abierta, a objeto de que los atentados más recurrentes a la buena fe se encuentren debidamente cubiertos. Por ello, se sostenido que, en materia de terminación contractual, la mayoría de las causales son un reflejo de la aplicación de este principio, tanto en su versión subjetiva como objetiva.

Con todo, existen a lo menos tres figuras extintivas especialmente relevantes y que reflejan (de manera no exclusiva) la opción de nuestro legislador por resguardar la buena fe en el ámbito del contrato de trabajo.

147 Cfr., García Viña, "La regulación actual", cit. nota n. 121, p. 13.

148 Cfr., artículos 78 y 83 del Código del Trabajo.

149 Vid. Montoya Melgar, La buena fe, cit. nota n. 15, p. 95. 


\subsection{La falta de probidad y la conducta inmoral grave}

El artículo $160 \mathrm{~N}^{\circ} 1 \mathrm{CT}$ faculta a que se pueda poner término al contrato de trabajo, sin derecho a indemnización, cuando el trabajador (o el empleador, si se trata de un despido indirecto) incurre en "falta de probidad" o en "conducta inmoral" grave y debidamente comprobada. Se trata de una norma que viene del Código del Trabajo del año 1931 y que mayoritariamente la jurisprudencia y la doctrina la han vinculado a supuestos en que se carece de integridad y honradez en el obrar ${ }^{150}$. Asimismo, la causal engloba la prohibición de conductas fraudulentas o que supongan abuso de confianza, y que eventualmente le puedan permitir al infractor obtener ventajas patrimoniales, mediante engaño, y que terminan perjudicando al empleador o a terceros ${ }^{151}$.

En este contexto, la prohibición de actos que supongan falta de probidad o conducta inmoral, no es más que el reflejo del principio general de buena fe ahora en el ámbito de las causales disciplinarias de despido ${ }^{152}$. Ambos conceptos - falta de probidad y conducta inmoral- se asocian a la idea de una carencia de honradez, de rectitud, de moralidad y de corrección en el desempeño de las funciones por parte de los sujetos contratantes ${ }^{153}$. Por ello, cada vez que el trabajador incurre en alguna de estas hipótesis, el legislador entiende que se comete una grave infracción a la buena fe contractual, admitiendo el término justificado de los servicios.

\footnotetext{
150 Una de los primeros fallos que vinculó a la falta de probidad o a la conducta inmoral con la carencia de integridad y honradez, fue la sentencia de 03 de julio de 1953, RDJ, T. L, sección tercera, 1953, p. 9. Criterios semejantes pueden consultarse en la Sentencia de la Excma. Corte Suprema de 06 de julio de 1988, GJ No 97 (1988), p. 78; Sentencia de la Iltma. Corte de Apelaciones de Concepción de 12 de septiembre de 1991, GJ № 136 (1991), p. 133; Sentencia de la Iltma. Corte de Apelaciones de Santiago de 12 de julio de 1991, GJ No 133 (1991), p. 109; Sentencia de la lltma. Corte de Apelaciones de Santiago de 21 de noviembre de 1990, GJ N 131 (1991), p. 112; Sentencia de la Iltma. Corte de Apelaciones de Copiapó de 13 de febrero de 2003, GJ № 275 (2003), p. 212; y Sentencia de la Iltma. Corte de Apelaciones de Santiago de 10 de septiembre de 2003, GJ № 279 (2003), p. 264. En el plano doctrinal, vid. por todos IRURETA URIARTE, Pedro, "La falta de probidad como causa de extinción del contrato de trabajo". Estudios en Homenaje al Profesor William Thayer A. Sociedad Chilena de Derecho del Trabajo y de la Seguridad Social, Santiago 1998, p. 117; y THAYER ARTEAGA, William, y Novoa Fuenzalida, Patricio, Manual de Derecho del Trabajo, T. I. Editorial Jurídica de Chile, $2^{\text {a }}$ edición, Santiago 1989, p. 387.

151 Vid. Sentencia de la Excma. Corte Suprema de 25 de junio de 2002, GJ № 274 (2003), p. 269: "Por probidad debe entenderse buena conducta, buena fe, recto comportamiento, honestidad, honor y corrección al obrar. Es un concepto que da cabida a toda suerte de exigencias éticas para obtener un comportamiento sincero y sin reservas, y está llamado a desarrollar hábitos sanos de comportamiento y que son necesarios para producir confianza en el ánimo de otros".

152 Cfr. Sentencia de la Iltma. Corte de Apelaciones de Santiago de 30 de enero de 1989, RDJ, T. LXXXVI, sección tercera (1989), p. 43.

${ }_{153}$ Cfr. Sentencia de la Iltma. Corte de Apelaciones de Copiapó de 13 de febrero de 2003, GJ № 275 (2003), p. 212.
} 
La norma del artículo $160 \mathrm{~N}^{\circ} 1 \mathrm{CT}$ exige dos requisitos para poder aplicar la causal: gravedad y comprobación debida. La gravedad de la conducta deriva de la propia naturaleza del obrar sancionado, sin que sea necesario que el acto que se reprocha sea coincidente con un tipo delictivo ${ }^{154}$. De esta manera, la gravedad se relaciona con el bien jurídico protegido lo que transforma en irrelevante, al menos en principio, el número de actos o los eventuales perjuicios ocasionados $^{155}$. Lo que la ley ha querido sancionar, en definitiva, son aquellas faltas que presentan tal nivel de relevancia, que el único camino viable es la extinción del contrato ${ }^{156}$. En cuanto a los deberes de comprobación, la norma lo que exige es que el acto extintivo no se fundamente en la mera sospecha o en la simple posibilidad. Por el contrario, debe existir una fundamentación acabada en la realidad, en que la comprobación realza la razonabilidad de la medida. Así lo ha exigido la jurisprudencia al declarar que un hecho no le es imputable al trabajador si no existe la debida acreditación del mismo ${ }^{157}$.

La vinculación entre falta de probidad o conducta inmoral, y buena fe contractual, resulta evidente. Este último concepto, al menos en su versión objetiva, exige que las partes lleven a cabo un comportamiento leal y correcto, honrado, que no deje lugar a dudas sobre la corrección en el obrar por parte del contratante. Por ello, la falta de probidad y la conducta inmoral son figuras que, ante todo, se oponen a ese obrar honrado que exige el principio de buena fe, razón por la cual se permite poner término justificadamente al contrato de trabajo.

\subsection{La prohibición de competencia desleal}

Un segundo supuesto relevante de protección de la buena fe -en el ámbito de extinción contractual- se encuentra en la norma del artículo 160 № 2 CT. En virtud de dicho precepto, el contrato de trabajo termina sin derecho a indemnización alguna cuando el empleador le ponga término invocando una o más de

\footnotetext{
${ }^{154}$ Cfr. Dieguez Cuervo, La fidelidad, cit. nota n. 16, p. 32. Y agrega: “(...) con lo que 'a contrario sensu' parece confirmarse el carácter 'desleal' de cualquier delito o falta".

155 En rigor, la gravedad de la conducta que se reprocha debe nacer de hechos más o menos instantáneos que ameritan la extinción inmediata del contrato. Lo anterior no impide, desde luego, que la gravedad provenga, también, de una serie de hechos que, "tomados en sí, no son de una gravedad equivalente a la de las causas de género agudo; pero cuya gravedad deriva de la continuidad" (vid. Barassi. I, Ludovico, Tratado de Derecho del Trabajo, T. III. Alfa, Buenos Aires 1953, p. 359).

156 Vid. IrUReta Uriarte, "La falta de probidad", cit. nota n. 150, p. 119. En plano jurisprudencial vid. entre otras: Sentencia de la Excma. Corte Suprema de 23 de abril de 1998, RDJ, T. XCV, sección tercera (1998), p. 45; Sentencia de la Excma. Corte Suprema de 03 de abril de 1997, RDJ, T. XCIV, sección tercera (1997), p. 35; y Sentencia de la Iltma. Corte de Apelaciones de Valparaíso, de 20 de octubre de 1983, GJ № 40 (1983), p. 113.

157 Vid. entre otras muchas, Sentencia de la Excma. Corte Suprema de 15 de abril de 1993. RFM № 412, marzo, 1993, p. 60; de 04 de marzo de 1992, GJ № 141 (1992), p. 79; de 09 de abril de 1991, GJ № 129 (1991), p. 81, y de 11 de septiembre de 1968, RDJ, T. LXV, sección tercera (1968), p. 140.
} 
las siguientes causales: "№ 2 Negociaciones que ejecute el trabajador dentro del giro del negocio y que hubieren sido prohibidas por escrito en el respectivo contrato por el empleador". Se trata de una norma cuyo principal objetivo es asegurarle al empleador un cierto grado de protección frente a eventuales ataques indebidos al libre ejercicio de su actividad, a sus instrumentos de actuación y a sus posibilidades comerciales. De esta forma, el legislador parte de la base que el empleador tiene derecho a evitar actividades competitivas provenientes de personas que, debido a su concreta posición jurídica al interior de la organización, tienen mejores posibilidades de competir con él ${ }^{158}$. Esta protección que el Código del Trabajo le dispensa al empleador, se encuentra vinculada con los deberes genéricos de lealtad y de buena fe contractual ${ }^{159}$. En atención a que los contratos deben cumplirse de buena fe, tal como lo dispone el artículo 1546 del Código Civil, ambos contratantes están obligados a no realizar actos en perjuicio de su contraparte. Y las actividades que supongan competencia desleal encuadran naturalmente con esa prohibición ${ }^{160}$.

El núcleo de esta causal consiste en prohibirle al trabajador la ejecución de negociaciones incompatibles, por cuenta propia o ajena, sin la debida autorización del empleador, provocando de esta manera un perjuicio real o potencial a los intereses económicos de éste ${ }^{161}$. Las negociaciones prohibidas se encuentran vinculadas con el giro del negocio del empleador, y dentro de ellas habrá que incorporar todas aquellas actividades que se desarrollan dentro del plano en que

158 Cfr., Nogueira Guastavino, Magdalena, La prohibición de competencia desleal en el contrato de trabajo. Aranzadi, Pamplona 1997, pp. 36 y 43.

159 Cfr. Novoa Fuenzalida, Patricio, "Deberes de fidelidad y lealtad laboral: no subsistencia de las obligaciones personales del trabajador una vez expirado el vínculo contractual y la competencia desleal", RLCH No 1 (1996), pp. 64 y ss.

160 Vid. IrUReta Uriarte, Pedro, "La prohibición de competencia y la buena fe contractual". Estudios Laborales № 1 (2007), p. 57. Vid. también Rodríguez-Piñero y Bravo-FerRer, Miguel, "Límites a la competencia y contrato de trabajo", RPS № 116 (1977), p. 11: "La honradez y limpieza del mercado es el valor que aparece en primer término: se trata de proteger a la empresa de los peligros que puedan derivarse de la posición privilegiada del trabajador que por conocer por dentro el negocio, tiene una extremada facilidad de aprovecharse de esta circunstancia (...). Esto no es sólo contrario a la buena fe, a la probidad, a la hombría de bien que ha de esperarse del trabajador, sino a la corrección y limpieza que debe exigirse a la competencia en el mercado. Por eso quien aprovechándose de esas circunstancias realizara un 'negocio' violaría la buena fe (...)".

161 Vid., entre otros, Dieguez Cuervo, La fidelidad, cit. nota n. 16, pp. 63 y ss.; Fernández López, "Competencia desleal: el cambio normativo y la posición de la jurisprudencia", RPS № 142 (1984), p. 246; IrUReta URiarte, "La prohibición de competencia", cit. nota n. 160, p. 58; RodríGuez-Piñero y BravoFerrer, "Límites a la competencia", cit. nota n. 160, p. 15; y Sempere Navarro, Antonio Vicente, "Despido disciplinario y preparación de la competencia desleal", AS Vol. V (1991), p. 26. 
efectúa las suyas la empresa principal, toda vez que inciden sobre un mismo mercado y sobre un mismo círculo de potenciales clientes ${ }^{162}$.

Una conducta como la que prohíbe el artículo $160 \mathrm{~N}^{\circ} 2 \mathrm{CT}$, deja al descubierto una actuación desleal por parte del trabajador, que quebranta la buena fe que debe imperar entre los contratantes, y que altera el libre juego económico. Por ello, para que se produzca la infracción a la buena fe no es preciso que se derive un especial beneficio para el trabajador, bastando para cometer el ilícito el hecho de que éste se coloque en una situación de beneficio derivada de la actividad competitiva. Aquí lo relevante es que puede llegar a producirse un perjuicio directo o potencial que terminará afectando los intereses del empleador, generándose de esta manera pretensiones contrapuestas entre las partes ${ }^{163}$.

En síntesis, si el trabajador se encuentra obligado por un genérico deber de lealtad, ello le impide abusar de la posición que ocupa en la empresa, perjudicando comercialmente a su empleador. Si así lo hiciera, quebranta la buena fe ${ }^{164}$.

\subsection{El incumplimiento grave de las obligaciones}

Una tercera causal de despido íntimamente unida a los deberes de buena fe se encuentra en el artículo 160 № 7 CT. En nuestro Código, el incumplimiento grave de las obligaciones constituye una infracción genérica, una especie de "cajón de sastre", donde es posible situar la mayor parte de los incumplimientos que ostenten una cierta gravedad, y que no tengan encuadre dentro de alguna de las otras hipótesis del artículo $160 \mathrm{CT}^{165}$. Por cierto, se trata de incumplimientos relevantes y circunscritos al propio contrato de trabajo ${ }^{166}$, de forma tal que infracciones irrelevantes, o ajenas al ámbito contractual, no pueden servir de fundamento para una causal de esta naturaleza.

El incumplimiento grave se encuentra asociado a las infracciones de la buena fe. Como se ha dicho, por la celebración del contrato, el trabajador se obliga

\footnotetext{
162 Vid. Iglesias CABero, Manuel, "Transgresión de la buena fe contractual". Estudios sobre el despido disciplinario. Acarl, Madrid 1992, p. 238.

163 Cfr. Escudero, Frigola y Corbella, El principio, cit. nota n. 3, pp. 86 y 87.

${ }^{164}$ Cfr. Novoa FuenZALIDA, "Deberes", cit. nota n. 159, p. 67. Incluso, este autor asocia esta causal a la misma falta de probidad: "La competencia desleal es, obviamente, una forma de falta de probidad".

${ }^{165}$ La utilidad de este tipo de causales es evidente, toda vez que resulta "imposible predecir qué tipo de conductas pueden producirse con el resultado de alterar el orden en la empresa. Fijar un riguroso listado de faltas, en suma, supondría congelar el estado de cosas en un determinado momento, sin posibilidad de tener en cuenta la multitud de imponderables que pueden concurrir en el caso concreto y que pueden aconsejar la sanción de un determinado comportamiento (...)". Vid. Fernández LópeZ, María Fernanda, El poder disciplinario en la empresa. Civitas, Madrid 1991, pp. 155 y 156.

166 Cfr., Sentencia de la Excma. Corte Suprema de 13 de junio de 2002, GJ № 264 (2002), pp. 207 y ss. Vid. también Sentencia de la Excma. Corte Suprema de 17 de septiembre de 2002, GJ № 267 (2002), pp. 158 y siguientes.
} 
a desempeñar las diversas obligaciones que derivan tanto del contrato mismo como aquellas que emanan de la ley y la costumbre. Si el trabajador falta a estos deberes contractuales mínimos, entonces falta a la buena fe y se sitúa en una posición que le impide ponderar adecuadamente el interés del empleador ${ }^{167}$.

El incumplimiento deja en evidencia un comportamiento desleal, ya que el sujeto obligado no ha ejecutado aquello a lo que se comprometió y que forma parte del iter negocial. Iguales conclusiones podrían predicarse de la conducta del empleador, en atención a la reciprocidad que subyace en la aplicación de este principio. Tanto es así que en el ámbito doctrinario se ha insistido en el hecho que la realización de acciones contrarias a la buena fe por parte del empleador, posibilitan que el trabajador ponga término al contrato por justa causa ${ }^{168}$.

Por cierto, la norma del artículo $160 \mathrm{~N}^{\circ} 7$ del Código del Trabajo no sanciona cualquier incumplimiento. Por el contrario, la norma hace referencia a infracciones importantes, trascendentes, de mucha entidad, serias, principales y frecuentes, que en definitiva demuestran una falta con entidad en sí misma, o que traiga aparejadas consecuencias relevantes para la empresa ${ }^{169}$. Se trata, en definitiva, de "no cumplir algo" relevante a lo cual se encuentra obligado el trabajador de conformidad al contrato de trabajo ${ }^{170}$. Con todo, en la lógica del artículo $160 \mathrm{~N}^{\circ} 7 \mathrm{CT}$, resulta irrelevante que los perjuicios sean directos o no, tampoco es relevante que sean ciertos o concretos; ni menos se precisa que los daños sean reales o simplemente potenciales. Por el contrario, es suficiente la existencia de una situación de riesgos de que tal cosa ocurra. Más aún, no hace falta que se aprecie ningún específico y concreto perjuicio sufrido por el empleador, ya que en definitiva el hecho en sí mismo puede ser suficiente para fundamentar un despido por incumplimiento contractual ${ }^{171}$.

${ }_{167}$ Cfr. Sentencia de la Iltma. Corte de Apelaciones de Santiago de 26 de mayo de 1986, RDJT. LXXXIII, sección tercera (1986), p. 99. El fallo ilustra la situación de un empleado bancario que fue despedido por haber otorgado un crédito a una persona que no presentaba la solvencia debida y con la cual, por lo demás, se encontraba vinculado comercialmente. La Corte estimó, en este caso, que el trabajador debió haber omitido todo acto que pudiese perjudicar a su empleador, "aun cuando él no le hubiera sido expresamente prohibido".

168 Cfr. Escudero, Frigola y Corbella, El principio, cit. nota n. 3, p. 78.

169 Cfr., Sentencia de la Iltma. Corte de Apelaciones de Santiago de 25 de junio de 2001, GJ № 252 (2001), pp. 193 y ss. En igual sentido, vid., Sentencia de la Iltma. Corte de Apelaciones de Concepción de 12 de noviembre de 2002, GJ № 269 (2002), pp. 182 y ss.; Sentencia de la Iltma. Corte de Apelaciones de Santiago de 10 de junio de 2002, GJ No 264 (2002), pp. 219 y ss.; y Sentencia de la lltma. Corte de Apelaciones de Copiapó de 21 de octubre de 2002, GJ № 271 (2003), pp. 183 y ss.

170 Vid., Sentencia de la Iltma. Corte de Apelaciones de Santiago de 27 de junio de 2002, GJ № 268 (2002), pp. 200 y 201.

171 Vid. en esta línea Aguilera Izquierdo, Raquel, Las causas del despido disciplinario y su valoración por la jurisprudencia. Aranzadi, Madrid 1997, p. 46: “(...) la escasa cuantía o el poco valor del bien defraudado es indiferente en el momento de enjuiciar la conducta, pues el engaño y el abuso de con- 


\section{ConcLusiones}

La estructura del contrato de trabajo presupone la existencia de la buena fe. Sin ella, los contratantes estarían obligados a regularlo todo, ya que siempre se estaría bajo la sospecha de que un actuar contrario al iter negocial carece de mecanismos correctores. Sin la buena fe, la regulación legal terminaría siendo sobreabundante, pretendiendo anteponerse a cualquier hipótesis que se desviara de un cumplimiento contractual conforme a los criterios de la lealtad y la corrección. Por ello, en materia laboral, la buena fe contractual tiene plena cabida.

La buena fe termina haciendo referencia a valores tradicionales y esenciales del ordenamiento jurídico, como son la confianza, la lealtad, la honradez o la rectitud de los contratantes. Si bien el Código del Trabajo no contiene un catálogo sistemático de referencias a la buena fe, en la práctica muchas de sus regulaciones dejan en evidencia un trasfondo regulatorio fundado precisamente en este principio.

Teniendo presente el carácter contractual del vínculo laboral, el orden normativo asume la buena fe como un elemento indispensable que permite asegurar que el contrato de trabajo discurrirá bajo los parámetros que el mismo ordenamiento ha prefigurado. En algunos casos, dicho ordenamiento ha optado por formalizar la buena fe en figuras específicas que considera esenciales de plasmar a objeto de evitar la arbitrariedad en el cumplimiento de los deberes contractuales. En otros casos, aun cuando pudiese existir silencio normativo, el ordenamiento asume que las eventuales vaguedades o ambigüedades de sus normas encuentran contención en este principio general. Por cierto, en la mayor parte de las hipótesis, el Código regula las figuras laborales desde la óptica de la buena fe objetiva; pero ello no impide que también se encuentren referencias a supuestos típicos de buena fe subjetiva.

Desde luego, la buena fe no sólo se aplica en el contexto de la relación individual. Tanto en el Derecho colectivo como en el orden procesal laboral, la buena fe juega un papel relevante; incluso, en este último ámbito, el legislador nacional la ha consagrado como un principio básico de los procedimientos del trabajo. Sin embargo, atendida la relevancia que tiene la buena fe en el Derecho de Obligaciones, no cabe duda que una de las manifestaciones más significativas del principio se produce precisamente en el ámbito del contrato individual de trabajo.

La jurisprudencia ha invocado las exigencias de la buena en una serie de figuras laborales. Básicamente, se le ha utilizado como una herramienta de corrección en el ejercicio de los derechos subjetivos. Ello se ha expresado, por ejemplo,

fianza son vicios que aun manifestándose sobre cosas de escasa valía económica la tienen de gran importancia para enjuiciar los actos realizados". 
en el reconocimiento de una responsabilidad derivada del injusto receso de las tratativas, en el quiebre de la confianza legítima o en el ejercicio contradictorio de una posición jurídica, en el abuso de la nulidad por motivos formales, en la anulación de actos abusivos, en la prohibición del poder formativo de resolución si el cumplimiento fue sustancial, en la aplicación de la teoría de los actos propios, en la prohibición de invocar abusivamente la excepción de contrato no cumplido, en accionar judicialmente para exigir algo que el mismo demandante debe restituir por otro motivo, o bien en los casos de retraso desleal en el ejercicio de un derecho. El uso jurisprudencial de estas herramientas ha dejado al descubierto una rica casuística, que obliga a delimitar las figuras propias del ordenamiento laboral. También ha ayudado a resolver las naturales tensiones que se producen entre principios generales y particularidades de la disciplina.

La aplicación de la buena fe en el ámbito laboral no puede hacer olvidar las reglas y directrices propias de esta rama jurídica, que obligan a tener en cuenta las mayores exigencias de trato correcto y leal entre los sujetos del contrato de trabajo. Lo anterior en caso alguno puede llevar a desconocer la idea preliminar de que el Derecho del Trabajo es una disciplina jurídica que participa de un sistema jurídico mayor que se valida en torno a los principios y valores que emanan de la Constitución.

La buena fe estructura deberes recíprocos para los sujetos del contrato de trabajo. Éstos discurren en toda la órbita del iter contractual, desde los tratos preliminares, la celebración del contrato preparatorio y/o definitivo, el cumplimiento del contrato e incluso en las relaciones post contractuales. En su aplicación, la buena fe no sólo es recíproca sino que tampoco admite grados, ya que no resulta factible que en un caso se puedan exigir mayores deberes de buena fe y en otros no. Por ello, debemos concluir que la buena fe no puede ser objeto de graduación numérica o proporcional, toda vez que, en definitiva, se actúa o no se actúa bajo el imperio de la buena fe.

\section{BibLIOGRAFÍA}

Aguilera IzQuierdo, Raquel, Las causas del despido disciplinario y su valoración por la jurisprudencia, Aranzadi, Madrid 1997.

AlCAíno ToRRES, Rodrigo, "La responsabilidad por el acto propio y su incorporación en el Derecho Civil chileno", TDD Año XIX Nº 1 y 2 (2004).

Almansa Pastor, José Manuel, "Los principios generales del Derecho en las fuentes normativas del Derecho del Trabajo", CCDT No 3, 1972.

Alonso Olea, Manuel, El despido. Instituto de Estudios Políticos, Madrid 1958.

Ángel Yagǘz, Ricardo de, Apariencia jurídica, posesión y publicidad inmobiliaria registral. Publicaciones Universidad de Deusto, Bilbao 1982. 
BarassI, Ludovico, Tratado de Derecho del Trabajo, T. III. Alfa, Buenos Aires 1953.

Baylos Grau, Antonio, Derecho del Trabajo: modelo para armar, Trotta, Madrid 1991.

- "El deber de lealtad del trabajador a la empresa. Obligación cualitativa y de carácter absoluto". RPS No 115, (1977).

BOetTIger PhiLIPPs, Camila, "El principio de la buena fe en la jurisprudencia de la Contraloría General de la República en materia urbanista", AJ № 19, T. I, Año X, 2009.

Borrajo Dacruz, Efrén, "El abuso de derecho en el Contrato de Trabajo". RDT No 1, Año I, 1954.

CaAmaño Rojo, Eduardo, "Análisis crítico sobre la aplicación de la doctrina de los actos propios en materia laboral", RDPUCV, Vol. XXXII, semestre I (2009).

CAPÓN FILAS, Rodolfo E., "El abuso del Derecho en relación al contrato de trabajo". Estudios de Derecho Individual de Trabajo en homenaje al profesor Mario L. Deveali. Heliasta S.R.L., Buenos Aires 1979.

Cardona Rubert, María Belén, "Tutela de la intimidad informática en el contrato de trabajo", RDS No 6 (1999).

Carretero SÁnchez, Santiago, "Un reducto para la libertad del juez: la doctrina de los actos propios y la buena fe", ADH Vol. 4, 2003.

Carrizosa Prieto, Esther, "El principio de proporcionalidad en el derecho del trabajo", REDT No 123, (2004).

CASAs BAAmOnde, María Emilia, "Irregularidad formal, fraude de ley y nulidad del despido disciplinario", Relaciones Laborales № 24 (1994).

Castán Tobeñas, José, Derecho Civil Español, Común y Foral, T. 1, Vol. I. Reus, reimpresión de la 14ª edición, Madrid 1987.

Castresana, Amelia, Fides, bona Fides: un concepto para la creación del derecho. Tecnos, Madrid 1991.

CattaneO, Giovanni, "Buonna FEDE objetiva e abuso del diritto", RTDPC Anno XXV No 3, 1971.

Conde Marín, Emilia, La buena fe en el contrato de trabajo. La Ley, $1^{\text {a }}$ edición, Madrid 2007.

CoRral TAlCIANI, Hernán, "La aplicación jurisprudencial de la buena fe objetiva en el ordenamiento civil chileno". Tratado de la Buena Fe en el Derecho. Director Marcos M. Córdoba. La Ley, Buenos Aires 2004.

Däubler, Wolfang, Derecho del Trabajo. Traducción de María Paz Acero Serna y Pío Acero López. Centro de Publicaciones Ministerio de Trabajo y Seguridad Social, Madrid 1994. 
De la Villa GiL, Enrique, "Los deberes éticos en el contrato de trabajo", RDTR $N^{\circ} 38$ (1960).

De los Mozos, José Luis, El principio de la buena fe. Bosch, Barcelona 1965.

Dieguez Cuervo, Gonzalo, La fidelidad del trabajador en LCT, Ediciones Universidad de Navarra, Pamplona 1969.

- Lecciones de Derecho del Trabajo. Civitas, 2a edición, Madrid 1988.

Díez-Picazo, Luis, La doctrina de los propios actos. Bosch, Barcelona 1963.

- prólogo a la obra de WIEACKER, Franz, El principio general de la buena fe. Traducción de José Luis Carro. Civitas, Madrid 1977.

EnneCCERUs, Ludwig, Kipp, Theodor, y Wolff, Martín, Tratado de Derecho Civil, T. II, Vol. I. Bosch, Barcelona 1947.

Escudero, J. F., Frigola, J., y Corbella, T., El principio de buena fe en el contrato de trabajo. Bosch, Barcelona 1996.

Fernández Domínguez, Juan José, Pruebas genéticas en el Derecho del Trabajo. Civitas, $1^{a}$ edición, Madrid 1999.

Fernández Gianottı, Enrique, "Fraude de derechos laborales", Relaciones Laborales, T. I, Madrid 1991.

FERNÁNDEZ LóPEZ, María Fernanda, "La transgresión de la buena fe contractual", RPS No 138 (1983).

- "Competencia desleal: el cambio normativo y la posición de la jurisprudencia", RPS No 142 (1984).

- El poder disciplinario en la empresa, Civitas, Madrid 1991.

FernánDeZ VILlazón, Luis Antonio, "Tratamiento automatizado de datos personales en los procesos de selección de trabajadores". Relaciones Laborales T. I (1994).

FerRara, Francisco, La simulación de los negocios jurídicos, EDERSA, Madrid 1960.

FerreiRa Rubio, Delia Matilde, La buena fe. El principio general en el Derecho Civil, Montecorvo, Madrid 1984.

FueYo LANERI, Fernando, Instituciones de Derecho Civil moderno, Editorial Jurídica de Chile, $1^{\text {a }}$ edición, Santiago 1990.

- El ejercicio abusivo del derecho, La Plata Revista del Colegio de Abogados, 1988.

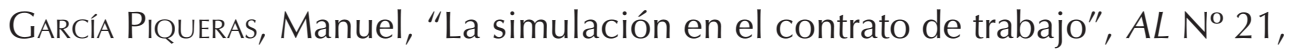
1990.

García Viña, Jordi, La buena fe en el contrato de trabajo. Consejo Económico Social, $1^{a}$ edición, Madrid 2001.

- "La regulación actual de la buena fe en la figura del empresario", AS № 22 (2000). 
- "El abuso de derecho y fraude de ley: análisis jurisprudencial", $A L N^{\circ} 45$, 1993.

Gil y Gil, José Luis, Principio de la buena fe y poderes del empresario. Consejo Andaluz de Relaciones Laborales, Sevilla 2003.

- "La buena fe en el contrato de trabajo", RTSS, octubre, (1996).

- Autotutela privada y poder disciplinario en la empresa. Centro de Publicaciones del Ministerio de Justicia, Madrid 1994.

Gómez-ACEBo, F., "La buena y la mala fe: su encuadramiento en la teoría general del Derecho y su eficacia en el Código Civil", RDP № 36 (1952).

GonzÁlez Ortega, Santiago, "La fidelidad a la empresa como obligación del trabajador: sentido y alcance en el marco de la relación laboral", RPS No 118 (1978).

- "Seguridad e higiene en el trabajo". Enciclopedia Jurídica Básica, T. IV. Dirección de Alfredo Montoya Melgar. Civitas, $1^{a}$ edición, Madrid 1995.

González Pérez, Jesús, El principio general de la buena fe en el Derecho Administrativo, Civitas, Madrid 1983.

González Rodríguez, Manuel, "Bocetos jurídicos: la buena fe y la seguridad jurídica", AAMN, T. III (1946).

GoÑı SeIN, José Luis, El respeto a la esfera privada del trabajador,Civitas, $1^{\text {a }}$ edición, Madrid 1988.

- "Límites constitucionales a los reconocimientos médicos obligatorios establecidos como medida de prevención de riesgos laborales", $R D S \mathrm{~N}^{\circ} 5$ (1999).

Grodeau, Michel J., "Lealtad y buena fe contractual", RCDI Nº 609 (1992).

Guzmán Brito, Alejandro, "La buena fe en el Código Civil de Chile", RCHD Vol. $29 \mathrm{~N}^{\circ} 1$ (2002).

Herrero Nieto, Bernardino, La simulación y el fraude a la ley en el Derecho del Trabajo. Bosch, Barcelona 1958.

Hueck, Alfred, y Nipperdey, H. C., Compendio de Derecho del Trabajo. Revista de Derecho Privado, Madrid 1963.

Iglesias Cabero, Manuel, "Transgresión de la buena fe contractual". Estudios sobre el despido disciplinario. Acarl, Madrid 1992.

IRURETA URIARTE, Pedro, "Estadios previos al contrato de trabajo: tratos preliminares y precontrato", Estudios Laborales № 2 (2008).

- "La falta de probidad como causa de extinción del contrato de trabajo". Estudios en Homenaje al Profesor William Thayer A. Sociedad Chilena de Derecho del Trabajo y de la Seguridad Social, Santiago 1998.

Iruzubieta Fernández, Rafael, El abuso del Derecho y el fraude de ley en el Derecho del Trabajo, Colex, Madrid 1989. 
Larenz, Kart, Derecho de Obligaciones, T. I. Versión española y notas de Jaime Santos Briz, Edersa, Madrid 1958.

LASARTE, Carlos, "Sobre la integración del contrato: la buena fe en la contratación (en torno a la sentencia del T.S. de 27 de enero de 1977)", RDP, enero, 1980.

LASTRA Lastra, José Manuel, "La buena fe en el trabajo: ¿un principio que se difumina?". Derecho y Conocimiento Volumen 3, Huelva, 2007.

López Santa María, Jorge, Los contratos (Parte General). Editorial Jurídica de Chile, $1^{\text {a }}$ edición, Santiago 1986.

LLuis NAVAS, Jaime, "El principio de buena fe en las relaciones laborales", RTL, Vol. 78, 1998.

Martins-Costa, Judith, "La buena fe objetiva y el cumplimiento de las obligaciones". Tratado de la Buena Fe en el Derecho, T. II. Director Marcos M. Córdoba. La Ley, Buenos Aires 2004.

Martínez Calcerrada, Luis, "La buena fe y el abuso del Derecho. Su respectiva caracterización como límites en el ejercicio de los derechos", $R D P N^{\circ} 63$ (1979).

Montoya Melgar, Alfredo, Derecho del Trabajo.Tecnos, 29a edición, Madrid 2008.

- La buena fe en el Derecho del Trabajo. Tecnos, Madrid 2001.

Moreno García, Antonio, "Buena fe y derechos fundamentales en la jurisprudencia del Tribunal Constitucional", REDC No 38 (1993).

Nogueira Guastavino, Magdalena, La prohibición de competencia desleal en el contrato de trabajo. Aranzadi, Pamplona, 1997.

Novoa Fuenzalida, Patricio, "Deberes de fidelidad y lealtad laboral: no subsistencia de las obligaciones personales del trabajador una vez expirado el vínculo contractual y la competencia desleal", RLCH No 1 (1996).

Peñallillo Arévalo, Daniel, "Titularidad real y titularidad aparente", RDDUC Nºs. 219-220 Año LXXIV (2006).

Plá Rodríguez, Américo, "Presencia actual de los principios del Derecho del Trabajo en América Latina", RLCH No 9-10 (1998).

- Los principios del Derecho del Trabajo. Depalma, $2^{a}$ edición, Buenos Aires 1978.

Rebollo Vargas, Rafael, "Los 'otros' límites al ejercicio de los derechos a la libertad de expresión e información: buena fe, honor de la empresa y deber de lealtad al empresario", CDP No 4 (1998).

Rodríguez-Piñero y Bravo-FerRer, Miguel, "Poder de dirección y derecho contractual". El Poder de Dirección del empresario. Nuevas perspectivas. La Ley, $1^{a}$ edición, Madrid 2005.

- "Límites a la competencia y contrato de trabajo", RPS № 116 (1977). 
Rodríguez-Sañudo GutiérRez, Fermín, "La transgresión de la buena fe contractual como causa de despido". Cuestiones Actuales de Derecho del Trabajo. Estudios ofrecido por los catedráticos españoles de Derecho del Trabajo al profesor Manuel Alonso Olea. Centro de Publicaciones Ministerio de Trabajo y Seguridad Social, Madrid 1990.

Román de la Torre, María Dolores, Poder de Dirección y Contrato de Trabajo. Grapheus, $1^{\text {a }}$ edición, Valladolid 1992.

Roqueta Bus, Remedios, El trabajo de los deportistas profesionales. Tirant lo Blanch, Valencia 1996.

RUIZ DE VelASCO, José María, "La buena fe como principio rector del ordenamiento jurídico español en relación con las prohibiciones del fraude de ley y del abuso del derecho", RGLJ Año CXXV, No 6 (1976).

Sagardor Bengochea, Juan Antonio, Los derechos fundamentales y el contrato de trabajo. Civitas, $1^{\text {a }}$ edición, Madrid 2005.

SaINz MoReno, Fernando, "La buena fe en las relaciones de la administración con los administrados", RAP No 89 (1979).

Sempere NaVArRo, Antonio Vicente, "Despido disciplinario y preparación de la competencia desleal", AS Vol. V (1991).

Sierra Herrero, Alfredo, Administradores de sociedades mercantiles y altos directivos laborales. Aranzadi, $1^{\text {a }}$ edición, Pamplona, 2008.

SupIot, Alain, Derecho del Trabajo. Traducción de Patricia Rubini-Blanco. Heliasta, Buenos Aires 2008.

Talón Martínez, Francisco T., "La apariencia jurídica", RJC, Año LI, Vol. LXIX, 1952.

Thayer Arteaga, William, y Novoa Fuenzalida, Patricio, Manual de Derecho del Trabajo, T. I. Editorial Jurídica de Chile, 2ª edición, Santiago 1989.

-Manual de Derecho del Trabajo, T. II. Editorial Jurídica de Chile, $3^{a}$ edición, Santiago 1998.

TuHR, Andreas V., "La buena fe en el Derecho romano y en el Derecho actual", $R D P N^{\circ} 146$ (1925).

VAldés Dal-Ré, Fernando, "Poderes del empresario y derechos de la persona del trabajador". Autoridad y Democracia en la empresa. Trotta, Madrid 1992.

Villaçá Azevedo, Marco de Almeida,"Buena fe objetiva y los deberes de ella derivados". Tratado de la Buena Fe en el Derecho, T. II. Director Marcos M. Córdoba. La Ley, Buenos Aires 2004.

Von Gierke, Otto, Las raíces del contrato de servicios, Civitas, reimpresión de la $1^{\text {a }}$ edición, Madrid 1989.

WIEACKER, Franz, El principio general de la buena fe, Traducción de José Luis Carro. Civitas, Madrid 1977. 
